Swarthmore College

Works

4-1-1984

\title{
The Iconography Of Theophilus Windows In The First Half Of The Thirteenth Century
}

Michael Watt Cothren

Swarthmore College, mcothre1@swarthmore.edu

Follow this and additional works at: https://works.swarthmore.edu/fac-art

Part of the Ancient, Medieval, Renaissance and Baroque Art and Architecture Commons

Let us know how access to these works benefits you

\section{Recommended Citation}

Michael Watt Cothren. (1984). "The Iconography Of Theophilus Windows In The First Half Of The

Thirteenth Century". Speculum. Volume 59, Issue 2. 308-341. DOI: 10.2307/2856394

https://works.swarthmore.edu/fac-art/17

This work is brought to you for free by Swarthmore College Libraries' Works. It has been accepted for inclusion in Art \& Art History Faculty Works by an authorized administrator of Works. For more information, please contact myworks@swarthmore.edu. 
The Iconography of Theophilus Windows in the First Half of the Thirteenth Century Author(s): Michael W. Cothren

Source: Speculum, Vol. 59, No. 2 (Apr., 1984), pp. 308-341

Published by: The University of Chicago Press

Stable URL: http://www.jstor.org/stable/2856394

Accessed: 27-09-2017 19:09 UTC

JSTOR is a not-for-profit service that helps scholars, researchers, and students discover, use, and build upon a wide range of content in a trusted digital archive. We use information technology and tools to increase productivity and facilitate new forms of scholarship. For more information about JSTOR, please contact support@jstor.org.

Your use of the JSTOR archive indicates your acceptance of the Terms \& Conditions of Use, available at http://about.jstor.org/terms

The University of Chicago Press is collaborating with JSTOR to digitize, preserve and extend access to Speculum 


\title{
The Iconography of Theophilus Windows in the First Half of the Thirteenth Century
}

\author{
By Michael W. Cothren
}

The legend of Theophilus the penitent is a frequent subject in thirteenthcentury stained glass windows. Although neither the story nor its illustration were inventions of the Gothic period, both reached a peak of popularity at that time. Theophilus became the subject of poems and plays as well as sermons, and was featured in manuscript illustrations and in architectual decoration, both sculpture and stained glass. ${ }^{1}$ The increasingly frequent illustration of the legend was matched by an increase in the number of scenes devoted to its depiction, especially in manuscripts and stained glass. Yet not since Alfred Freyer's rather cursory catalogue of illustrations of the Theophilus legend in medieval art has there been any attempt to coordinate and interpret the rich evidence provided by this narrative efflorescence. ${ }^{2}$

The legend of Theophilus is a simple and appealing story, easily summarized. ${ }^{3}$ As vidame, or temporal administrator, of the bishop of Sicily, the virtuous Theophilus fulfilled his responsibilities in exemplary fashion, and

This study, parts of which were given in papers at the Fifteenth International Congress on Medieval Studies (Kalamazoo, May 1980) and the Lilly-Pennsylvania Colloquium on Sacred and Profane (University of Pennsylvania, April 1983), began as part of the research for my dissertation on the Gothic windows of the cathedral of Beauvais, which was directed by Jane Hayward and supported by two Chester Dale Fellowships at the Metropolitan Museum of Art. Further research was supported by the Penrose Fund of the American Philosophical Society and the Faculty Research Fund of Swarthmore College. Special thanks are due to Julia Walworth, who worked with me as a research assistant on the transcription and translation of the commentaries of the Bibles moralisées. I would also like to express my gratitude to Elizabeth A. R. Brown, Meredith Lillich, and Susan Lowry; and to Luke Wenger and the Speculum readers, all of whose wise counsel helped in many ways in the preparation of this article.

${ }^{1}$ For thirteenth-century written versions of the legend see $n .7$ below. For its illustration in manuscripts and windows see Appendices A and B. For an example of architectural sculpture on the tympanum of the north transept portal of the cathedral of Paris, see Willibald Sauerländer, Gothic Sculpture in France, 1140-1270 (New York, 1972), pl. 186.

${ }^{2}$ Alfred Freyer, "Theophilus the Penitent as Represented in Art," Archaeological Jourmal 92 (1935), 287-333. An earlier study by a French amateur is more generalized, less comprehensive, and more rhapsodic, but it does concentrate on windows, occasionally addressing the effects of nineteenth-century restoration on their iconographic reliability: Ernest Faligan, "Des formes iconographiques de la légende de Théophile," Revue des traditions populaires 5 (1890), 1-14.

${ }^{3}$ This summary is generalized from the thirteenth-century written accounts of Gautier de Coincy, Rutebeuf, and Jacobus de Voragine: see $n$. 7 below. 
upon the death of the bishop the chapter pleaded with Theophilus to become his successor. Feeling too humble to be raised to the episcopacy, Theophilus begged the chapter not to impose the honor on him, and another man was named bishop. As fate would have it, the new bishop soon dismissed Theophilus, who was so disillusioned by his unjust treatment that he abandoned his virtuous life. Working through a Jewish sorcerer, Theophilus negotiated and sealed a pact with the devil. In return for renunciation of his belief in Christ and the Virgin, Theophilus contracted to recover his former position and rise again to power and wealth. Theophilus's hypocrisy brought him more worldly rewards than had his prior piety, but remorse eventually led him to violate his pact with the devil. Entering a chapel of the Virgin, he implored her to come to his aid. Responding to his contrition and his new profession of faith, the Virgin journeyed to Hell, wrenched the sealed pact from the devil, and returned it to Theophilus, thereby freeing him from his servitude. Soon afterwards, Theophilus died and went to heaven.

The Theophilus legend originated in the Greek East but appears in Western Latin literature as early as the eighth century in the translation of Paulus Diaconus. ${ }^{4}$ By the eleventh century a reference to Theophilus had been incorporated into the liturgy, ${ }^{5}$ and during the eleventh and twelfth centuries the story of his fall and salvation was a popular exemplum, appearing in the sermons of Honorius of Autun, Fulbert of Chartres, and Marbod of Rennes. ${ }^{6}$ But the legend was most popular in the thirteenth century, when it attracted the notice of writers such as Gautier de Coincy, Rutebeuf, and Jacobus de Voragine. ${ }^{7}$

\footnotetext{
${ }^{4}$ For the history of the Theophilus legend and its literary tradition in the West see Karl Plenzat, Die Theophiluslegende in der Dichtung des Mittelalters, Germanische Studien 43 (Berlin, 1926); Freyer, "Theophilus," pp. 287-91 (many written versions are cited in n. 1, pp. 290-91); Meyer Schapiro, "The Sculptures of Souillac," in Medieval Studies in Memory of A. Kingsley Porter, 2 (Cambridge, 1939), 378-80; and R. V. Dobschutz in Lexikon der christlichen Ikonographie, ed. E. Kirschbaum et al. (Freiburg, 1968-76), 4:593-96.

${ }^{5}$ Ulysse Chevalier, Poésies liturgiques traditionelles de l'église catholique en Occident (Tournai, 1893), p. 134.

${ }^{6}$ For Honorius of Autun see PL 172:993; for Fulbert of Chartres see PL 149:323-24; and for Marbod of Rennes see PL 171:1593-1604.

${ }^{7}$ For Gautier de Coincy see Les miracles de Nostre Dame, ed. V. F. Koenig (Geneva, 1966), 1:50-177; for Rutebeuf see "Le miracle de Théophile," Euvres complètes de Rutebeuf, ed. J. Bastin (Paris, 1960), 2:167-203; and for Jacobus de Voragine see The Golden Legend, trans. and ed. Granger Ryan and Helmut Ripperger (New York, 1941), pp. 528-29. For a thirteenth-century English version see The Early South-English Legendary or Lives of Saints (MS. Laud, 108, in the Bodleian Library), ed. Carl Horstmann, EETS 87 (London, 1887), pp. 288-93. See also a comparison of the treatment of the legend in four thirteenth-century collections of miracles of the Virgin in Sondra Roslyn Heller, "The Characterization of the Virgin Mary in Four Thirteenth Century Narrative Collections of Miracles: Jacobus de Voragine's Legenda Aurea, Gonzalo de Berceo's Milagros de Nuestra Señora, Gautier de Coincy's Miracles de Nostre Dame, and Alfonso el Sabio's Cantigas de Santa Maria," Dissertation, New York University, 1975, pp. 94-105.
} 
The idea of illustrating the story took hold more slowly. The earliest preserved image that represents any part of the legend is an iconic, historiated initial depicting Theophilus's prayer to the Virgin in an eleventhcentury anthology of saints' lives and sermons (Paris, BN, MS lat. 11750, fol. 51r). ${ }^{8}$ The next known representation of the legend, which is also the earliest preserved narrative cycle, is found in an early-twelfth-century stone relief now mounted on the interior west wall of the abbey church of Souillac. ${ }^{9}$ This relief employs three episodes to tell the legend of Theophilus. For the thirteenth century, I have found ten cycles in French and English manuscripts. Three of these devote ten or more separate episodes to illustrate the legend..$^{10}$ In French stained glass of the same period, where the illustration of the legend seems to have been more popular than in any other medium or at any other time in its history, the cycles are usually even more extensive, generally occupying an entire lancet. ${ }^{11}$ Substantial portions of eight French window cycles dating from the first half of the thirteenth century have survived at Auxerre, Beauvais, Laon, Le Mans, Saint-Juliendu-Sault, and Troyes; and single panels remain from what seem to have been comparable windows at Angers, Dreux, and Gercy. These windows and

${ }^{8}$ The Theophilus initial (illustrated in Schapiro, "Sculptures of Souillac," fig. 15, p. 381), the most elaborate of three major decorated initials in this manuscript, introduces a text of the legend as the first in a series of Miracles of the Virgin. For this manuscript see Yves Deslandes, "Les manuscrits décorés du XIe siècle à Saint-Germain-des-Prés," Scriptorium 9 (1955), 3-16.

${ }^{9}$ See Schapiro, "Sculptures of Souillac"; and cf. Jacques Thirion, "Observations sur les fragments sculptés du portail de Souillac," Gesta 15 (1976), 161-71.

${ }^{10}$ See Appendix B, especially nos. 1, 2, and 8.

${ }^{11}$ Once the decision had been made to devote an entire window to the legend of Theophilus, the size of the space available for illustration led logically to the development of an expanded window cycle. What concerns me here is how, once called upon to do so, the artists or the authors of the window programs enlarged narrative cycles of the legend to fill the lavish spaces put at their disposal. Once this has been established, it may be possible to speculate as to why this particular story was chosen for such expanded treatment in the first place. The legend of Theophilus does not always occupy an entire window during the thirteenth century. Scenes from his life are sometimes included in windows portraying episodes drawn from various of the Virgin's miracles, such as that in the nave aisle of the cathedral of Chartres (Yves Delaporte and Etienne Houvet, Les vitraux de la cathédrale de Chartres, 1 [Chartres, 1926], 189-95) and perhaps that in the ambulatory glazing at the Cathedral of Tours (Linda Papanicolaou, "Stained Glass Windows of the Choir of the Cathedral of Tours," Dissertation, New York University, 1979, pp. 135-36, pl. 104). The inclusion of Theophilus in such cycles of the Virgin's miracles is not my subject here, but rather the cycles produced when a separate window was devoted to this particular miracle alone. Of all the Virgin's miracles, only the Theophilus legend was extracted from such anthologies to appear frequently on its own in thirteenth-century architectural decoration. Its preeminence is perhaps best exemplified by the program of the Virgin Chapel at Le Mans, where instead of being included in the window containing highlights of several of the Virgin's miracles, the story of Theophilus was reserved from the anthology to be the subject of a separate window (for which see Appendix A, no. 2). 
their distinctive pictorial recension of the legend of Theophilus will be the subject of this study. ${ }^{12}$

Four scenes from the legend form the core of all the pictorial cycles, regardless of medium. Focusing on the role of the devil and the Virgin, they express the central theme of the miracle and are highlighted in written versions of the legend. The involvement of the devil is represented by a single episode: the sealing of the pact binding Theophilus to him. The role of the Virgin in saving Theophilus from his damnable fate was a more popular theme, represented by three principal episodes: Theophilus's prayer to her, her recovery of the pact from the devil, and her return of the pact to Theophilus. Every cycle contains at least two of these four scenes. In a cycle of five or more scenes, all four usually appear. ${ }^{13}$

When pictorial cycles were expanded to include a larger number of scenes, the episodes that were added in manuscripts were generally not the same as those added in windows. In the case of manuscript illumination, the additional scenes were drawn most often from the events preceding Theophilus's pact with the devil, events which explain the reasons for his fall from grace rather than its consequences. These include the scene of his dismissal from office and meetings between the disgraced Theophilus and the Jewish sorcerer who acts as an agent of the devil. The longest cycles also include scenes subsequent to Theophilus's repentance and salvation, such as his death and burial. ${ }^{14}$ Since all these events are emphasized in literary versions of the

${ }^{12}$ Since many thirteenth-century French windows have been lost, there were doubtless others. At the cathedral of Bourges, for instance, in the Virgin Chapel whose windows have not survived, there well may have been a Theophilus window as there is at Le Mans, Beauvais, and Auxerre. In addition, it is possible that there were thirteenth-century English windows adhering to the same cycle used in French windows, but the surviving evidence permits no firm conclusions about them. One scene (now lost) from the Theophilus legend was included in the tenth typological window at Canterbury Cathedral. See Madeline Caviness, The Early Stained Glass of Canterbury Cathedral, c. 1175-1220 (Princeton, 1977), p. 118 and appendix fig. 16. Although four panels remain at Lincoln and two at York from what could have been Theophilus windows, none of the most distinctive scenes of the French cycles are represented among the remains. But the appearance at Lincoln of the scene of Theophilus offering the regained pact to the bishop, an episode more characteristic of French window cycles than those in manuscripts (cf. Appendices A and B) suggests that the hypothetical Lincoln window could have been similar to those that are the subject of this study. For these panels see Jean Lafond, "The Stained Glass of Lincoln Cathedral in the Thirteenth Century," Archaeological Journal 103 (1946), 132-33. Since scenes from other miracles of the Virgin also appear among the debris of the Lincoln glazing, the possibility that the Theophilus scenes were part of an anthology window of scenes from several of the Virgin's miracles - like those discussed in the previous note - cannot be eliminated.

${ }^{13}$ For examples see Appendices A and B. Note Appendix B, no. 5, where the cycle is composed exclusively of the four core episodes.

${ }^{14}$ For examples of manuscript cycles see Appendix B. The exceptional case of Besançon, Bibliothèque Municipale, MS 551 , will be discussed below. 
legend, such as the contemporary poem of Gautier de Coincy, there would seem to have been a textual basis for the expansion of the pictorial cycles in manuscripts.

The most elaborate Theophilus windows encompass the same temporal span as the manuscript cycles, beginning with a few episodes preceding the pact and ending with Theophilus's death, but they have a different focus. The expansion of the window cycles is effected primarily by adding events between Theophilus's pact and his repentance, events in which Theophilus executes the duties and enjoys the rewards secured as a result of his agreement with the devil. Three scenes are most popular. In the first of these (Fig. 1), the reinstated Theophilus is shown distributing alms that have been given to him by a devil, who generally appears beside him to provide the crucial temporal clue that situates the scene after the pact. Although Theophilus appears to be virtuous, the presence of his patron perverts his seeming piety. In the second and most curious of these scenes (Figs. 2 and 3b), the enthroned Theophilus receives a fish from an approaching figure. In the third scene (Figs. 3a and 4a), the vidame is depicted supervising the construction of a church, perhaps the one he is shown entering in a subsequent scene to offer his prayer to the Virgin. These episodes, frequent in window cycles, appear only exceptionally within manuscript cycles, ${ }^{15}$ and they never appear as a group except in windows. Unlike the scenes chosen to amplify manuscript cycles, none of them seems to have been based on an event described in a text of the Theophilus legend.

In addition to this series of scenes illustrating events between Theophilus's pact and his repentance, the most elaborate window cycles generally incorporate a series of episodes subsequent to the Virgin's recovery of the pact, illustrating his penance. In the most common additional scene, Theophilus appears offering the regained pact to the bishop. Another scene that often follows this one is unique to window cycles and, like the three scenes discussed above, seems not to have been included in written accounts of the legend. It shows Theophilus stripped to the waist and kneeling before the bishop, who sits with a bundle of switches in his hand, presumably waiting to administer punishment (Fig. 5b). The bishop is occasionally depicted in still a third scene (Fig. 5a), in which he explains the events that have transpired to an emblematic congregation or to an assembly of clerics, perhaps using Theophilus as the subject of a sermon about the power of the Virgin. It is

\footnotetext{
${ }^{15}$ See Appendix B, nos. 1 and 8. As will be discussed below, the inclusion of the scene of the presentation of the fish in Besançon 551 may be a case of influence from the window on a manuscript cycle. The scene of the distribution of alms in Munich Clm 17401 (where Theophilus appears to be reproached by rather than inspired by a devil) seems to represent the first stage of Theophilus's repentance - as it does in Gautier de Coincy's poem and in Besançon 551 (see n. 29 below) - rather than the hypocritical activity during his tenure with the devil that is represented by the scene in window cycles.
} 


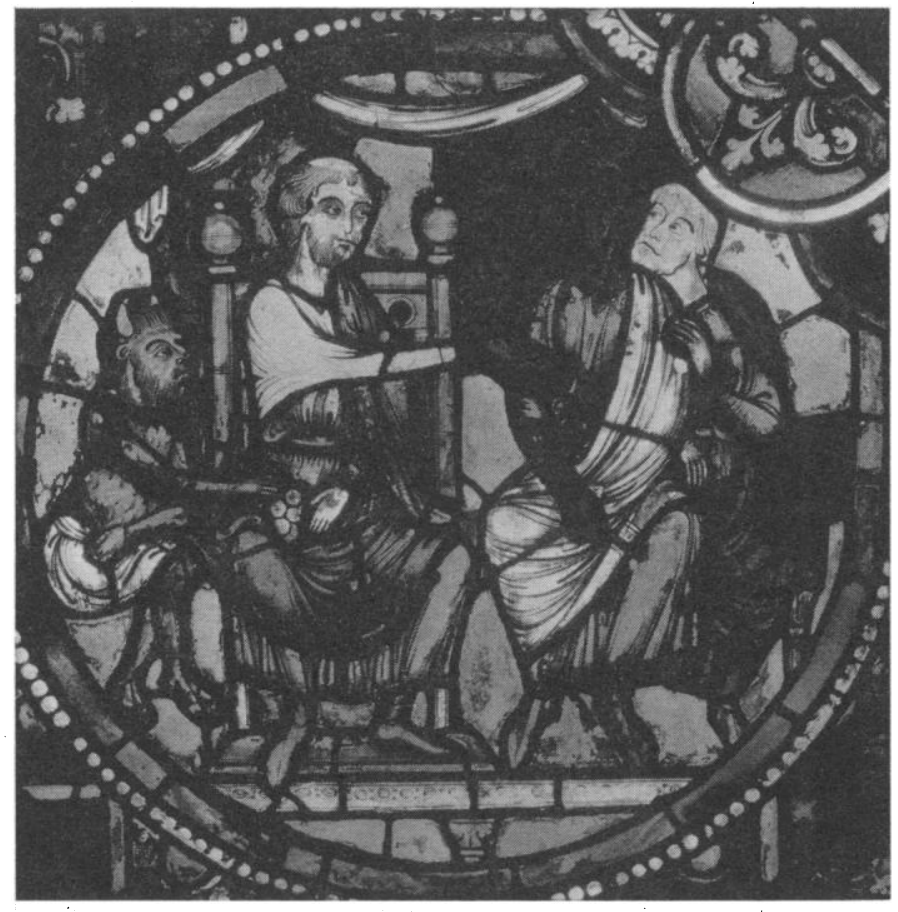

1 Theophilus distributing alms

Theophilus window, Cathedral of Laon, Eastern terminal wall (detail) (Photo: (1) ARCH.PHOTO/VAGA, New York/SPADEM)

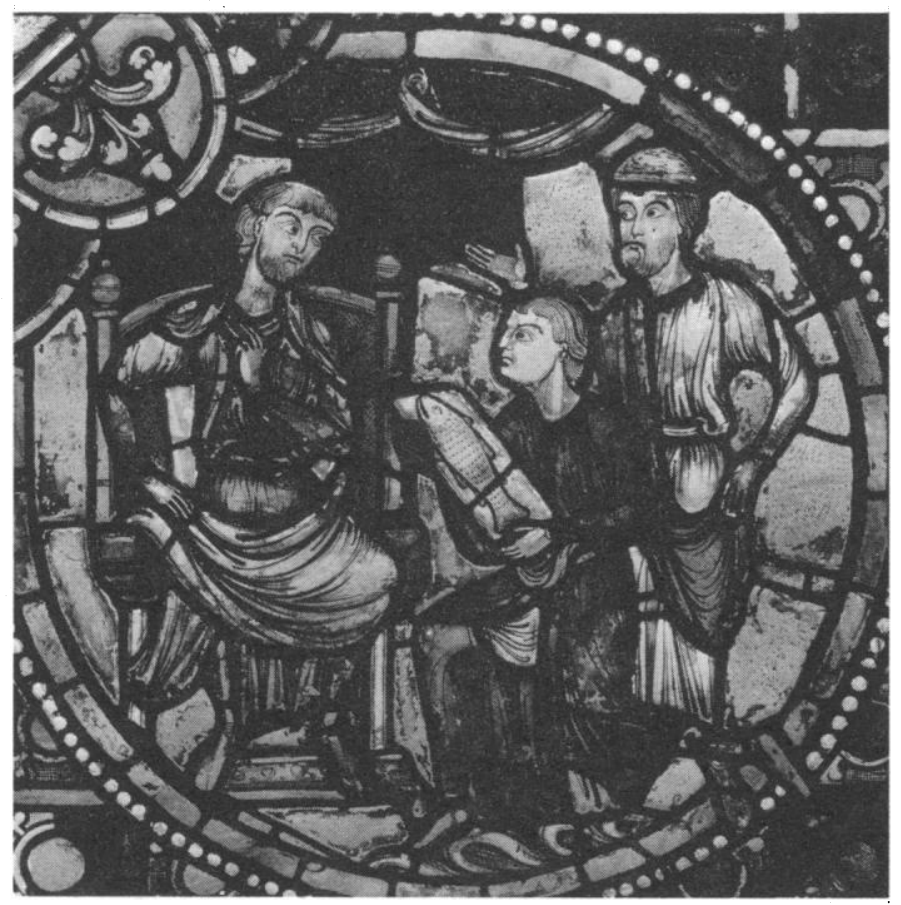

2 Theophilus receiving a fish

Theophilus window, Cathedral of Laon, Eastern terminal wall (detail) (Photo: () ARCH.PHOTO/VAGA, New York/SPADEM) 

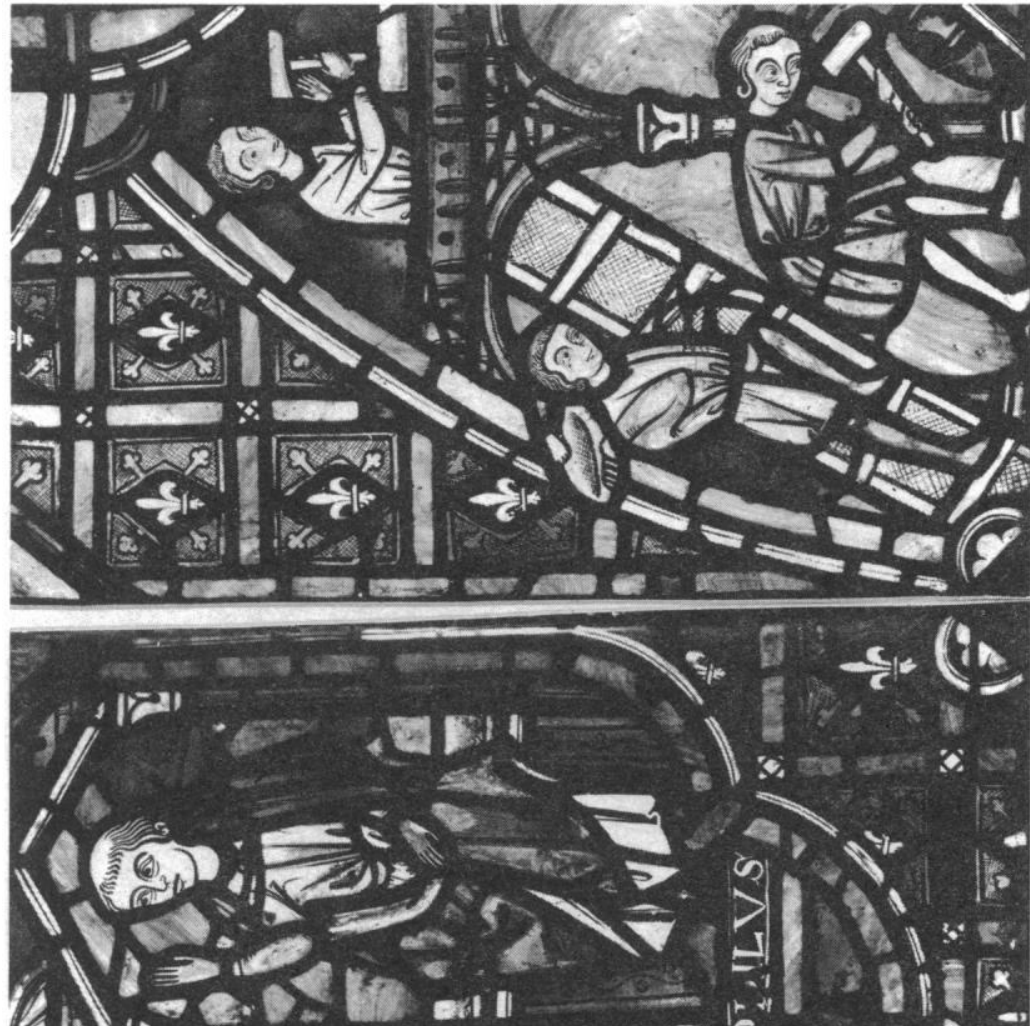

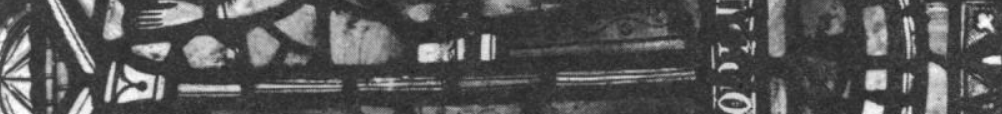

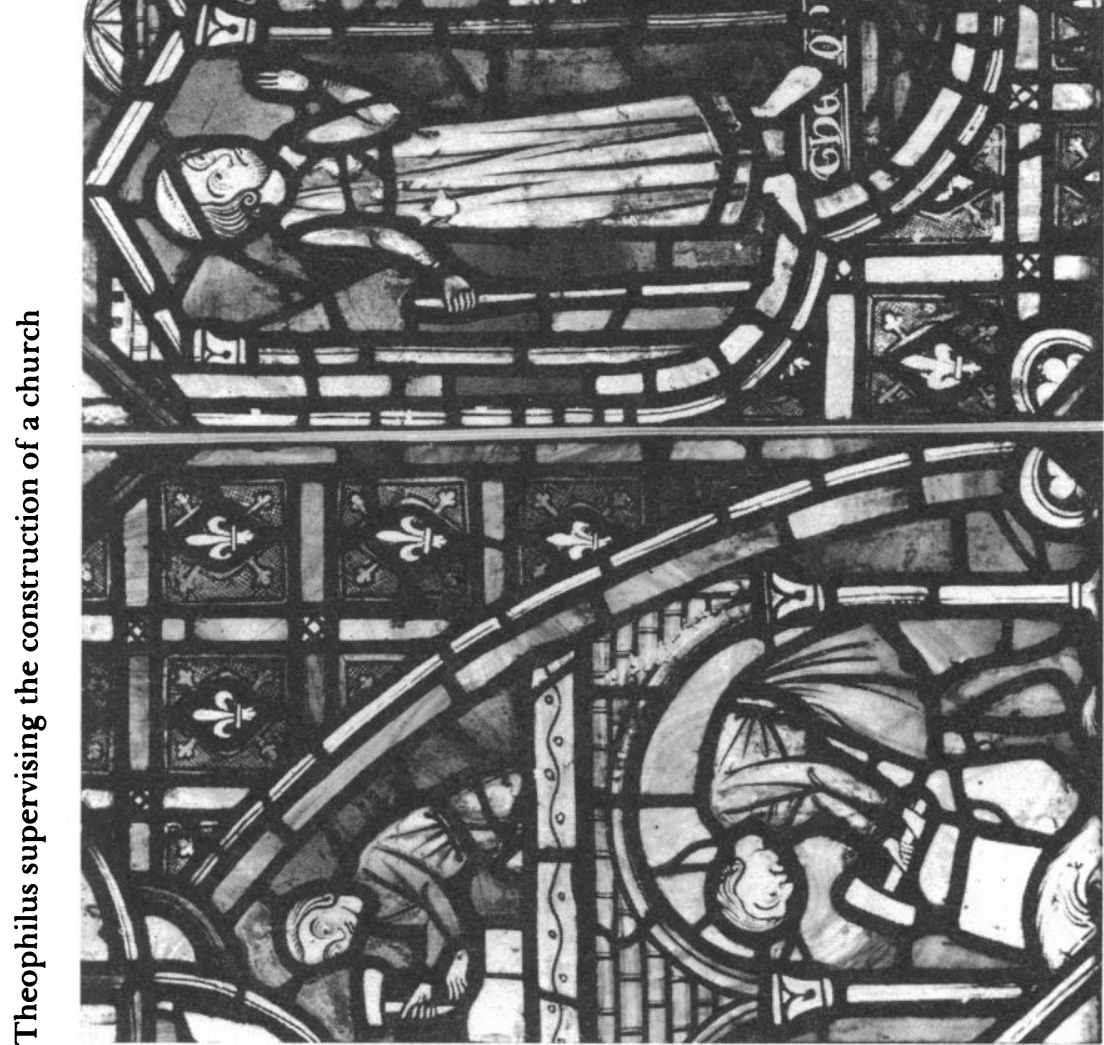



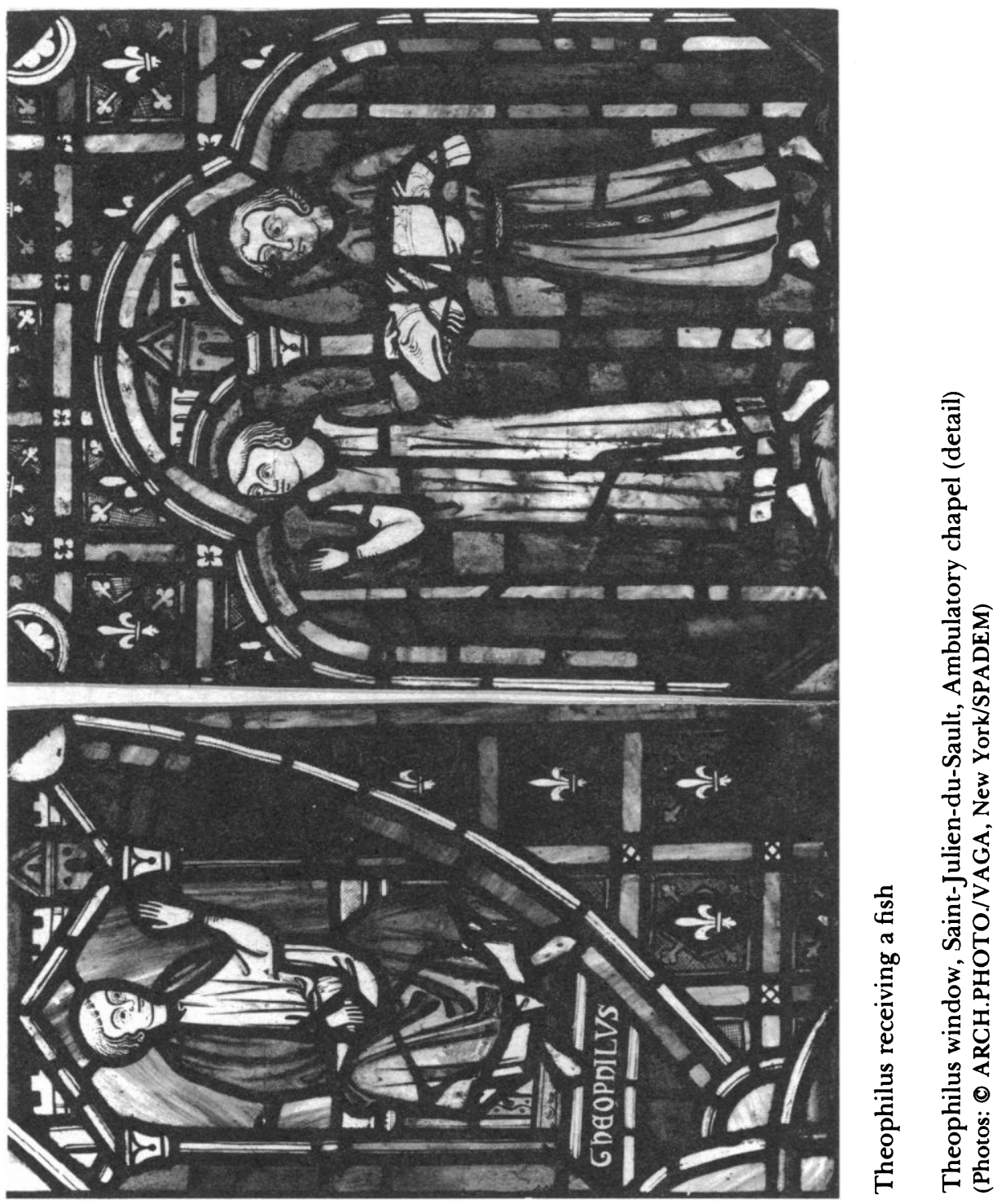

की All use subject to http://about.jstor.org/terms 
$4 \mathrm{a}$ Theophilus supervising the construction of a church
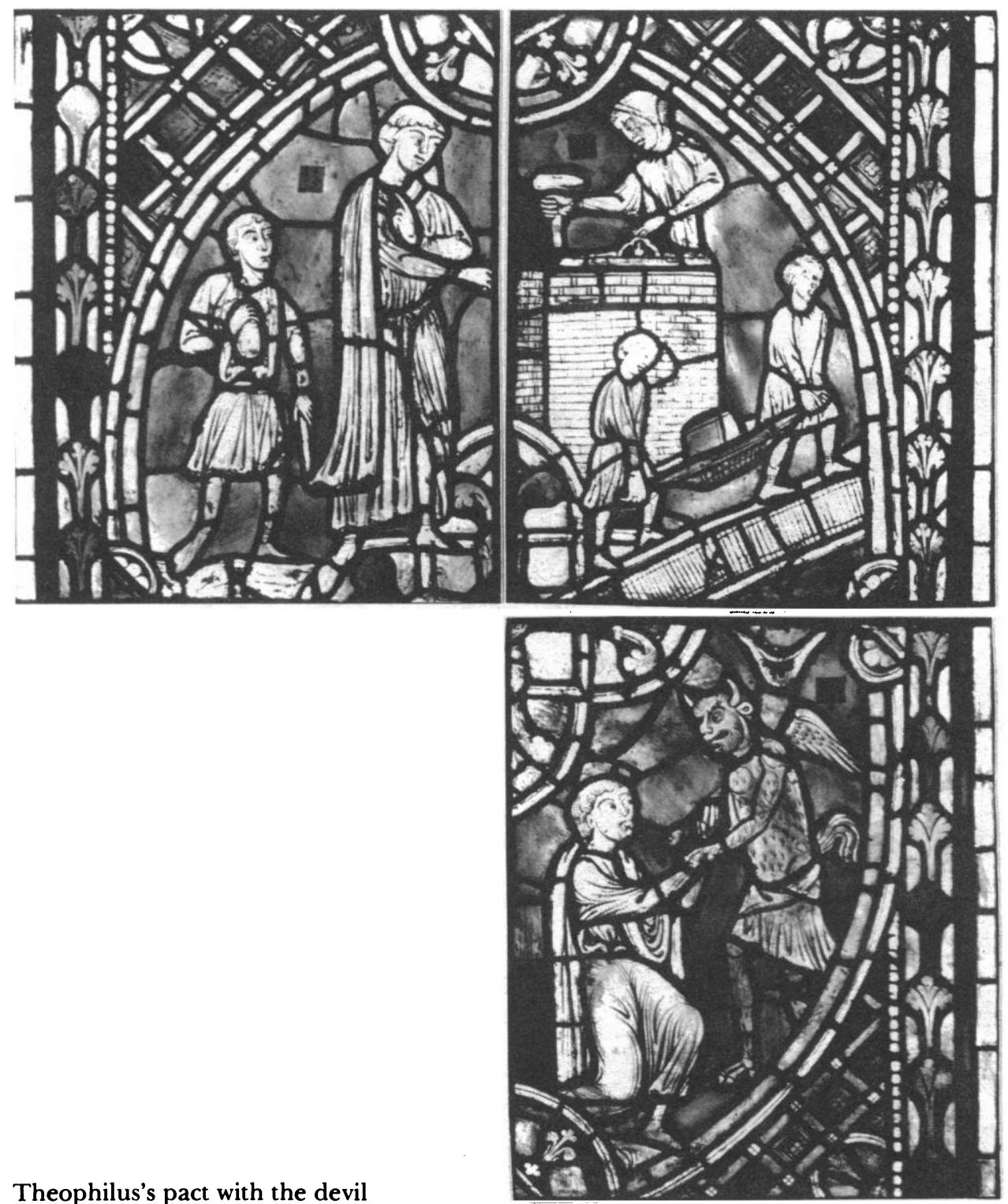

$4 \mathrm{~b}$ Theophilus's pact with the devil

Theophilus window, Cathedral of Beauvais, Virgin chapel (detail)

(Photos: $\odot$ ARCH.PHOTO/VAGA, New York/SPADEM) 
$5 \mathrm{a}$ The bishop's sermon about Theophilus
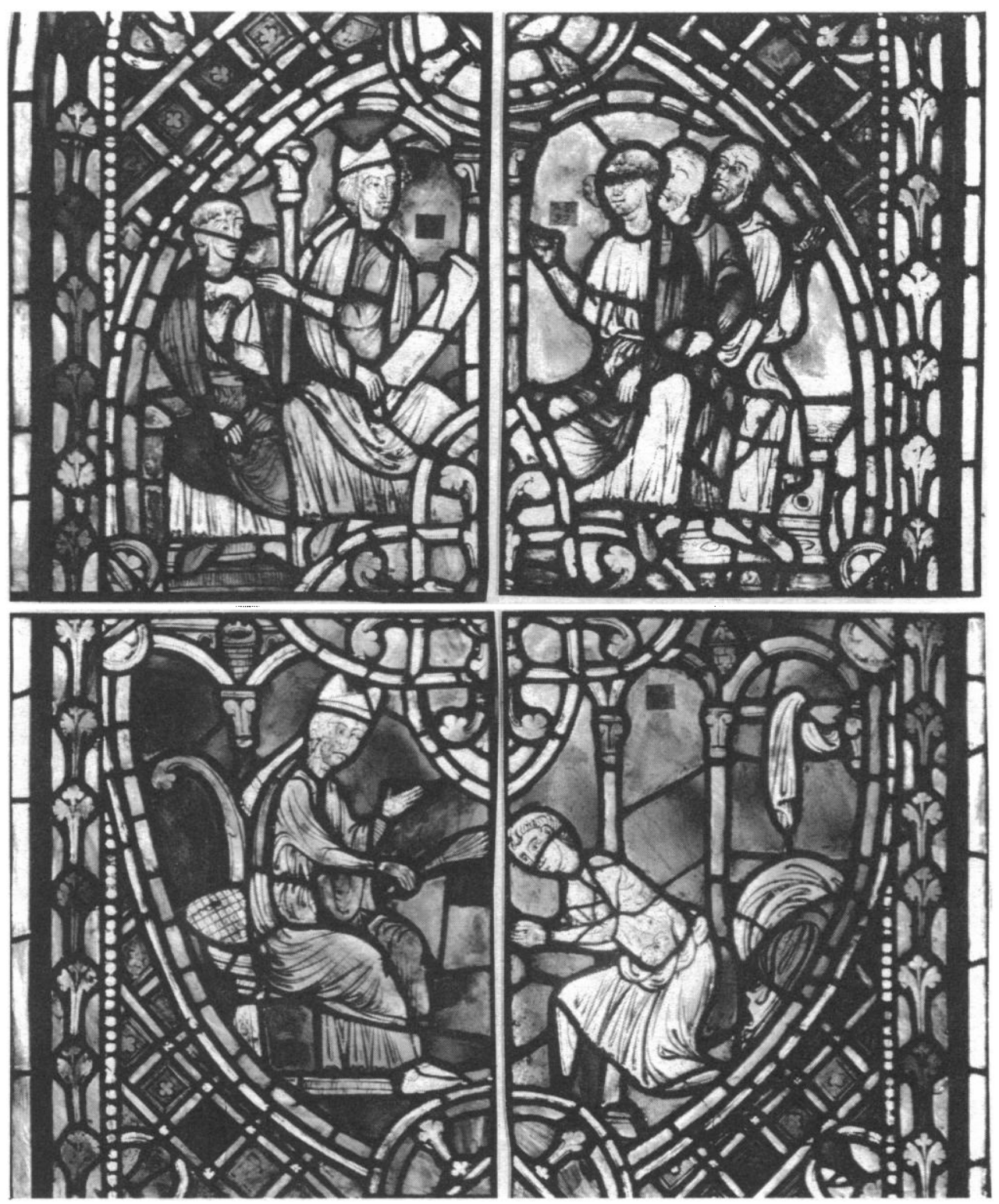

$5 \mathrm{~b}$ Theophilus's penance

Theophilus window, Cathedral of Beauvais, Virgin chapel (detail)

(Photos: () ARCH.PHOTO./VAGA, New York/SPADEM) 


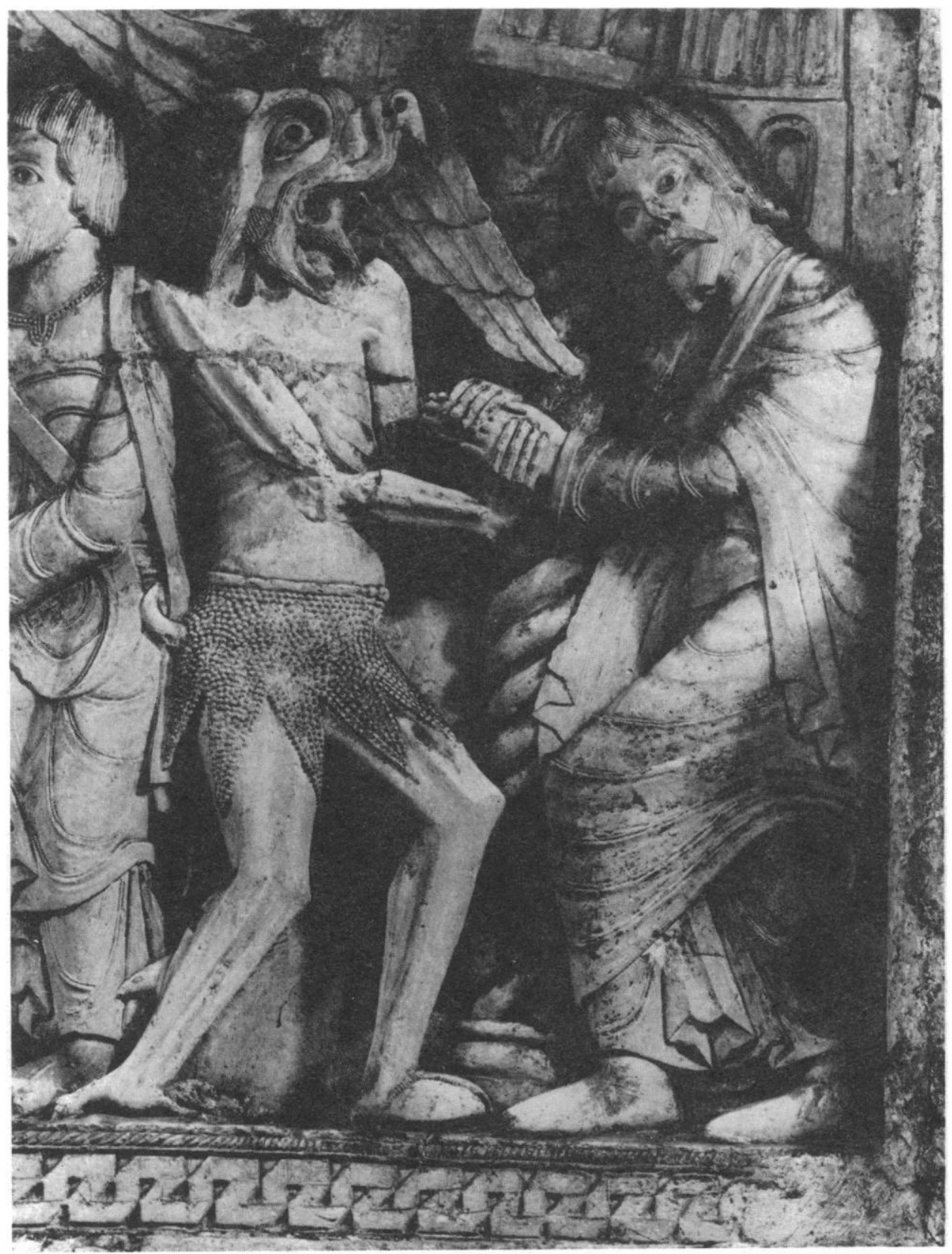

6 Theophilus's pact with the devil

Relief, Abbey church of Souillac (detail)

(Photo: Bildarchiv Foto Marburg) 


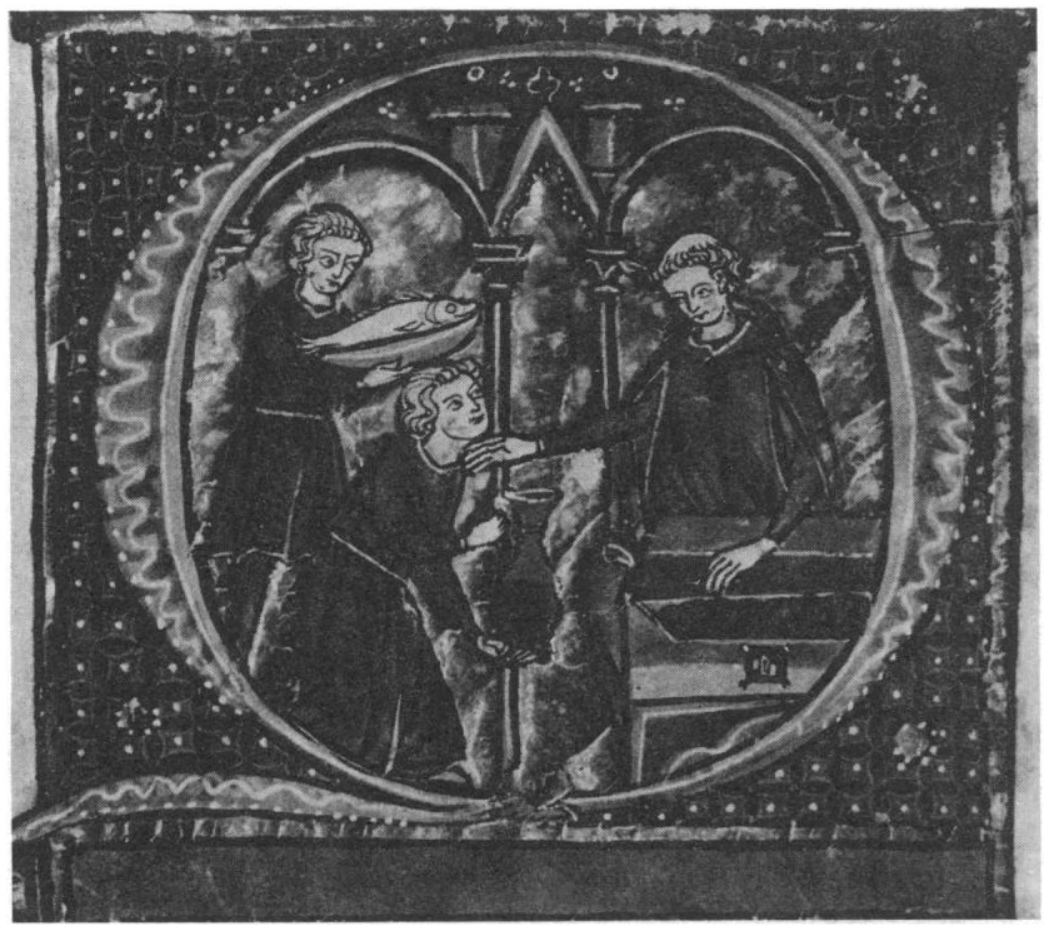

7 Theophilus receiving a fish

Besançon, Bibliothèque municipale, MS 551, fol. 9r (detail)

(Photo: Susan Lowry)

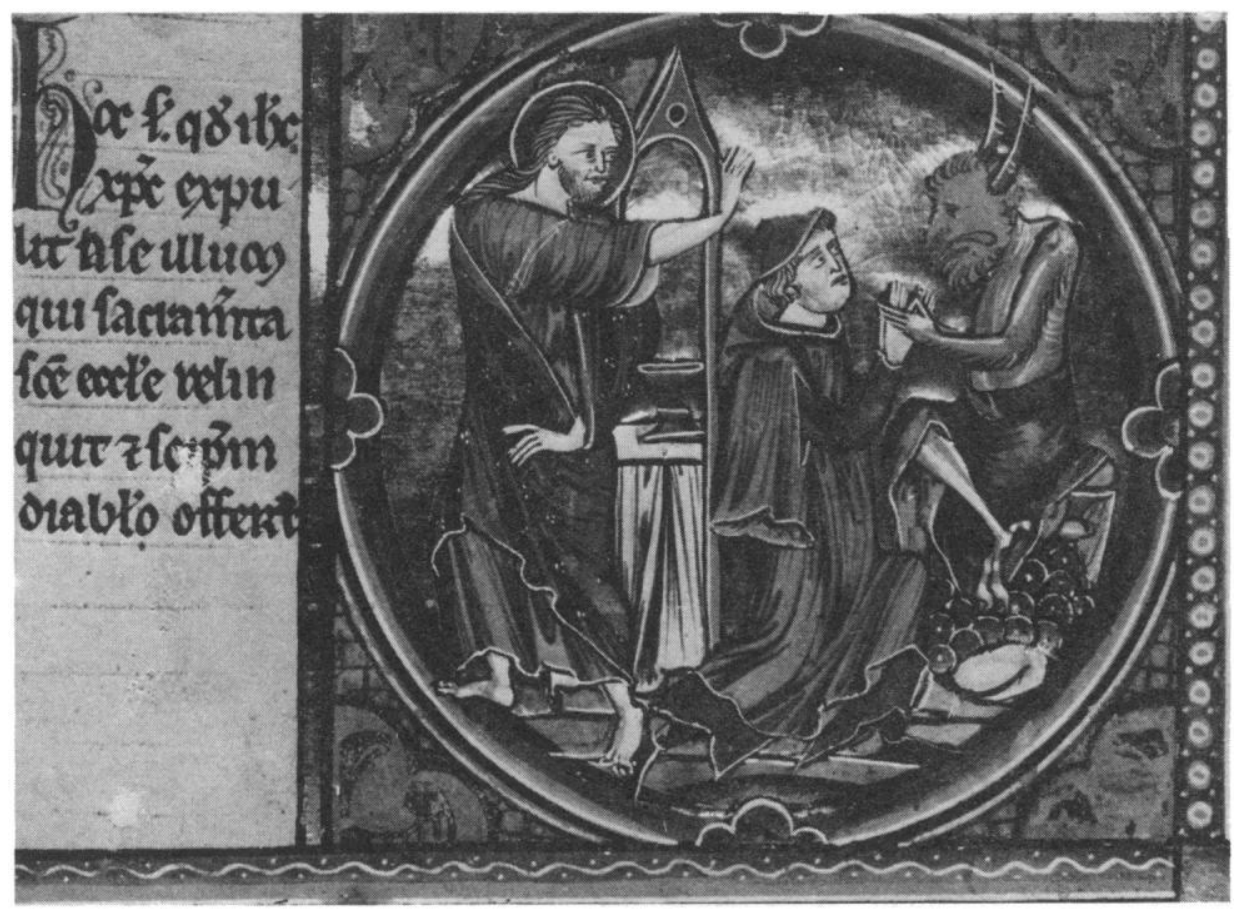

8 A pact with the devil

Vienna, Österreichische Nationalbibliothek, MS 1179, fol. 51r (detail) (Photo: ÖNB) 


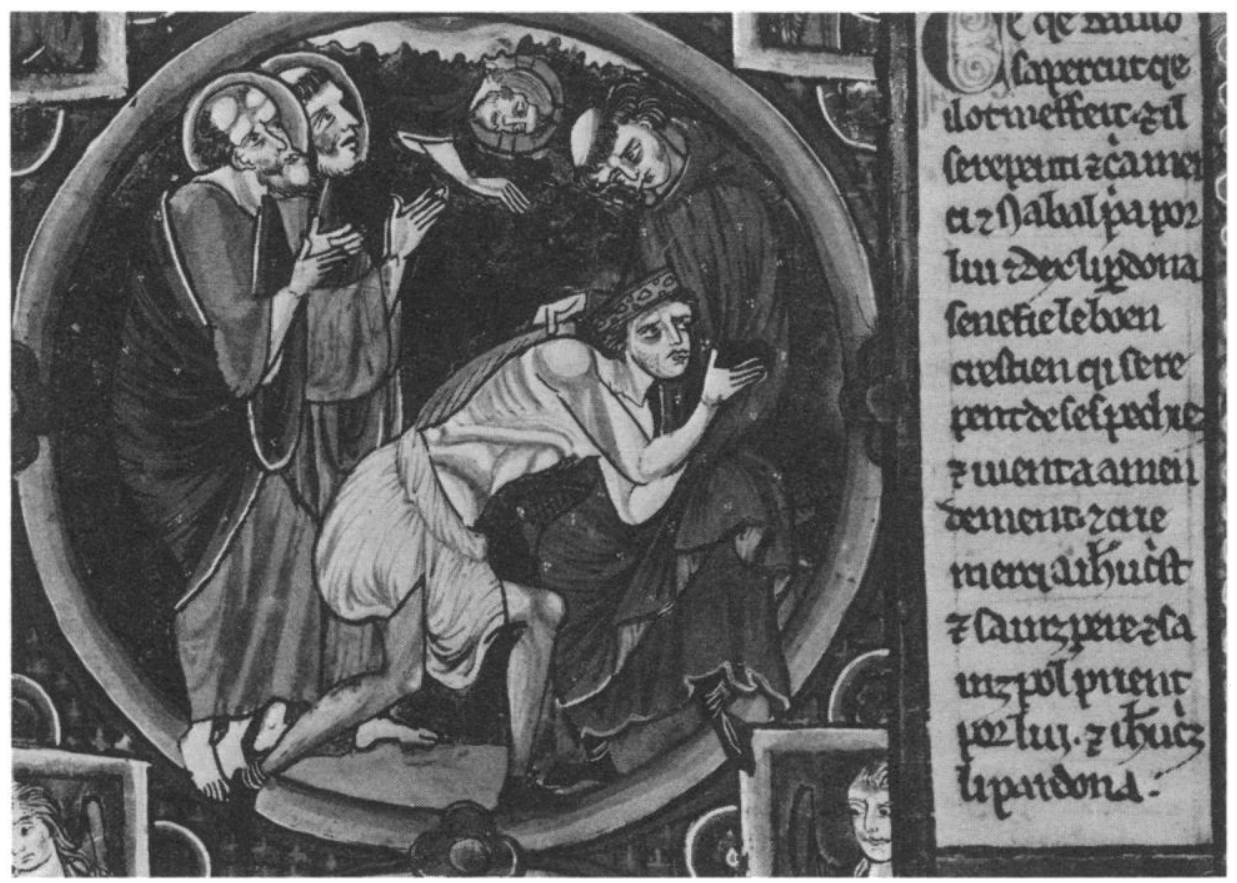

9 Penitential scourging

Vienna, Österreichische Nationalbibliothek, MS 2554, fol. 46r (detail) (Photo: ÖNB)

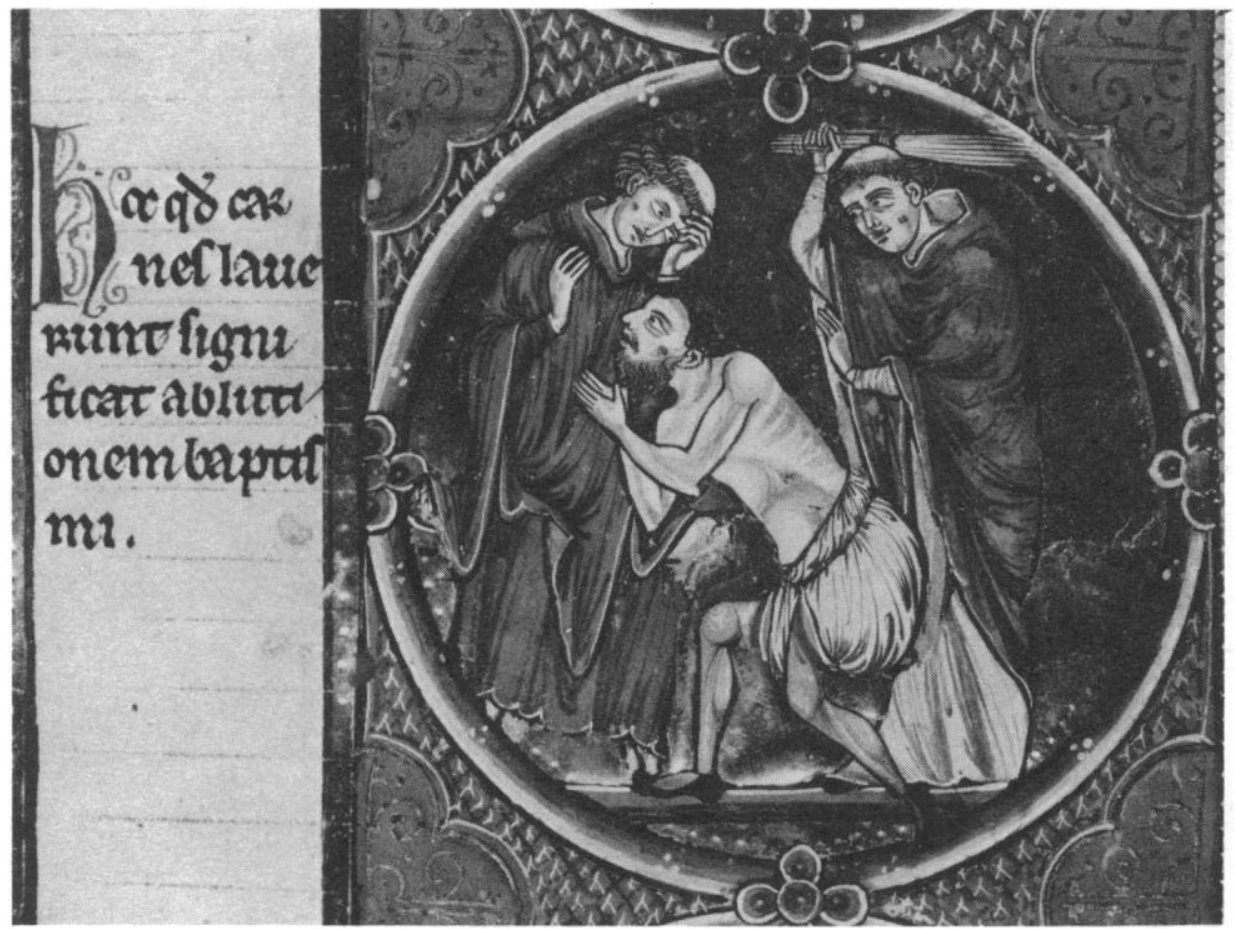

10 Penitential scourging

Vienna, Österreichische Nationalbibliothek, MS 1179, fol. 43r (detail) (Photo: ÓNB) 


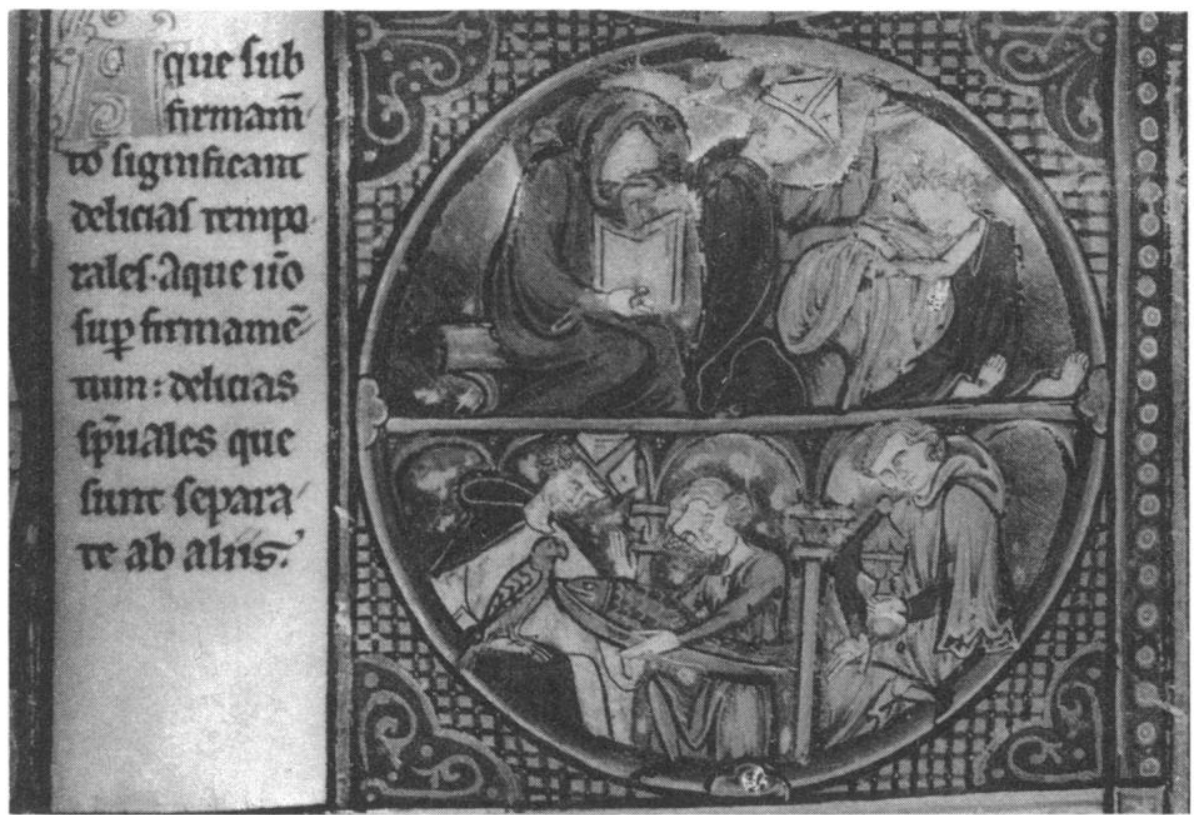

11 One bishop distributing to the poor, another receiving worldly riches Toledo, Biblioteca del Cabildo, MS 1, fol. 2r (detail) (Photo: MAS)

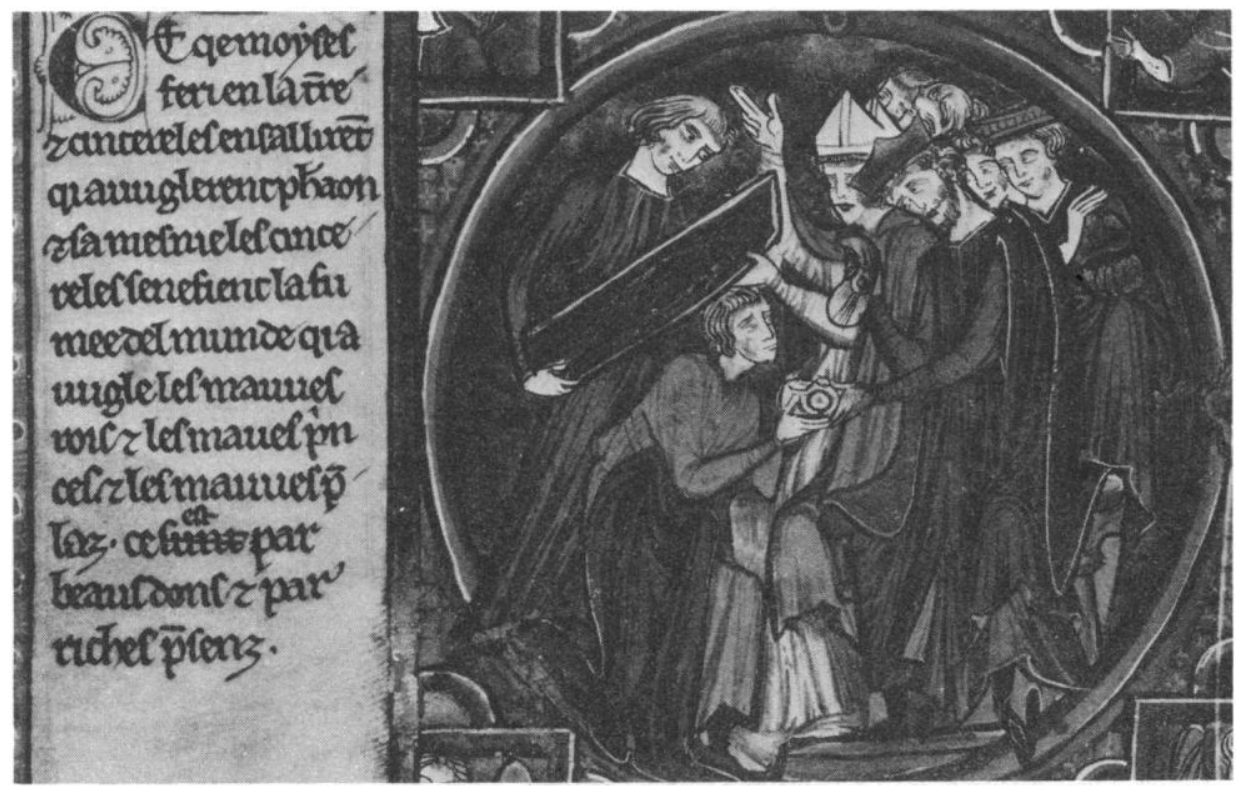

12 The temptation of worldly riches

Vienna, Österreichische Nationalbibliothek, MS 2554, fol. 19v (detail) (Photo: ÖNB) 


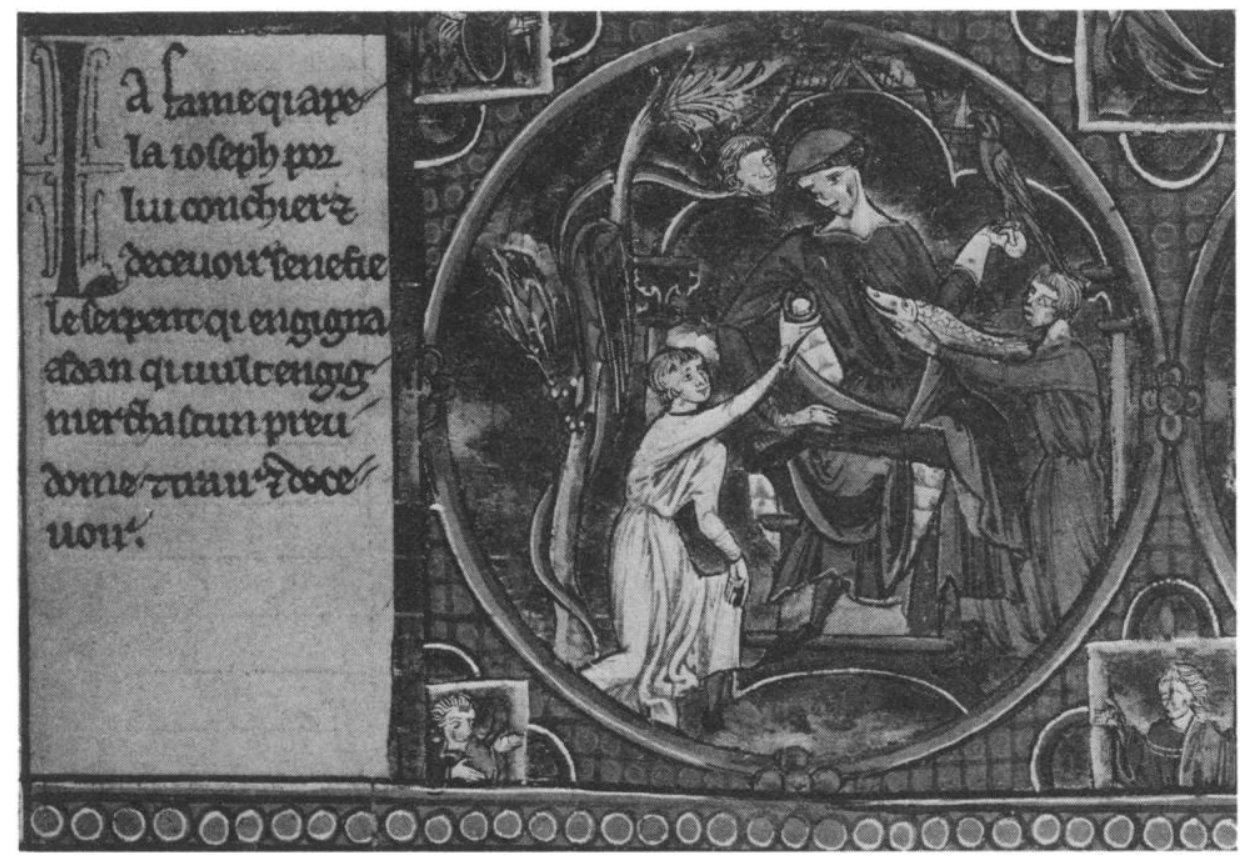

13 The temptation of worldly riches

Vienna, Österreichische Nationalbibliothek, MS 2554, fol. 8v (detail) (Photo: ÖNB)

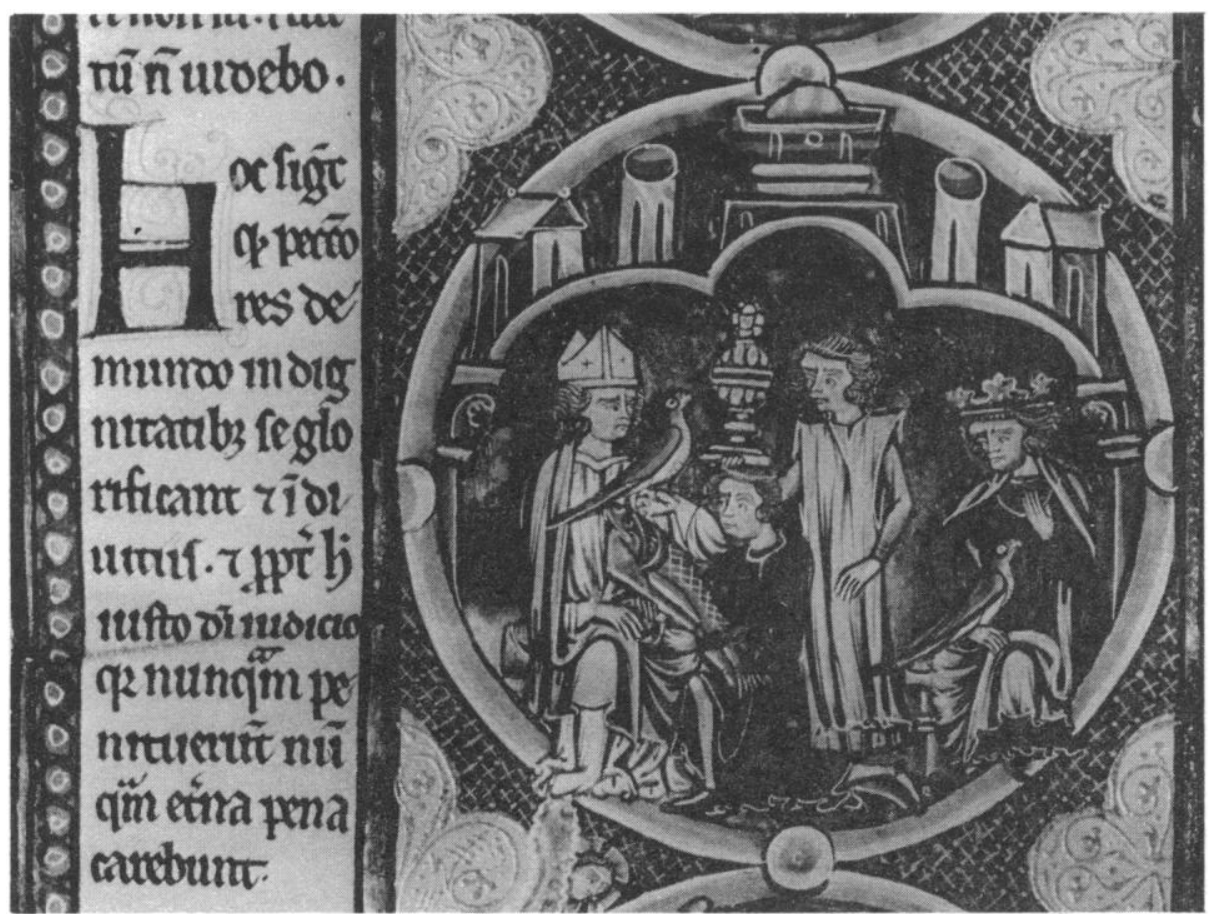

14 The reception of worldly riches

Toledo, Biblioteca del Cabildo, MS 3, fol. 189r (detail)

(Photo: MAS) 
clear then, that when the legend of Theophilus was expanded in window cycles, the emphasis was placed on the result of the two acts that dominated Theophilus's life - his fall and his repentance - rather than on the reasons for those actions. ${ }^{16}$

Determining the distinctiveness of a stained glass recension of the Theophilus legend is rather simple ${ }^{17}$ requiring only the compilation and

${ }^{16}$ An additional and curious scene, depicting devils attacking a building (from which Theophilus is fleeing in some cases), is often included in Theophilus windows, but it does not always appear at the same point in the narrative. Never appearing in manuscripts, however, it must be a part of the glass recension. Interpretations of its still enigmatic meaning have varied according to its position within particular window narratives. At Laon and Troyes it follows Theophilus's dismissal as vidame near the beginning of the cycle and has been explained as Theophilus's revenge after his dismissal (André Marsat, Cathédrale de Troyes: Les vitraux [Paris and Troyes, 1977], p. 64). It could also represent devils delighting in Theophilus's demise. At Auxerre, as at Saint-Julien-du-Sault, the scene appears after Theophilus's repentance and has been described as the destruction by demons of the church they had helped to build - that is, the revenge of the devil against Theophilus's treachery (Virginia Chieffo Raguin, "ThirteenthCentury Choir Glass of Auxerre Cathedral," Dissertation, Yale, 1974, p. 213). Determining the order of episodes, however, is a common problem in the study of window narratives; the frequent use of modular designs increases the probability of erroneous transpositions of panels in post-medieval restorations. Because the Theophilus windows at Auxerre and Saint-Juliendu-Sault are heavily restored, and because they are composed of a few frequently repeated shapes, their original arrangements are particularly difficult to determine. On the other hand, the more structured design of the window at Laon - the earliest extant Theophilus window secures the placement of this scene just after Theophilus's dismissal. Whether the position of the scene at Auxerre and Saint-Julian-du-Sault is due to a thirteenth-century iconographic alteration or to a nineteenth-century misinstallation can only be determined after a more detailed study of the two windows.

${ }^{17}$ By proposing a separate stained glass recension for the legend of Theophilus, I do not mean to suggest unswerving fidelity to a single, codified cycle composed of a series of unalterable compositions. The close relationships between the cycles in windows, revealed most clearly in the inclusion of a group of unusual, shared scenes, justifies their discussion as members of an iconographic recension, even if all the scenes do not appear in every window (see Appendix A), and even if the shared episodes are not always composed in identical fashion (cf. the presentation of the fish in Figs. 2 and $3 \mathrm{~b}$ ). That the unusual scenes appearing with such regularity in the windows are rarely found in cycles in other media is the most striking evidence for the isolation of a stained glass recension. Since many windows have been lost, a precise evaluation of the internal relationships between windows within the recension, leading to a stemma, may be impossible. But some windows clearly are more closely related to each other than to others in the group. For instance, the window at Beauvais (c. 1245) is so close iconographically to the window at Laon (c. 1215) that its cycle, containing scenes composed in almost identical fashion, must be derived from the earlier window in some direct manner. For the relationship between these windows see Michael Watt Cothren, "The Thirteenth and Fourteenth-Century Glazing of the Choir of the Cathedral of Beauvais," Dissertation, Columbia University, 1980, pp. 130-37. Furthermore, a single panel from a Theophilus window once at Gercy, now in the Musée de Cluny (see Louis Grodecki, in Cathédrales, exhibition catalogue, Musée de Louvre [Paris, 1962], entry 152), seems to document the existence of the Laon version of the window recension near Paris before it traveled to Beauvais. How the cycle migrated is as unclear as the exact relationship between the windows of Laon and Beauvais, on the one hand, and the others in the larger recension that share scenes with Laon and Beauvais, but compose them in a slightly different manner. 
comparison of the available cycles in all media. The reasons for the formation of the window cycle and the sources for the individual scenes that are unique to it, however, are more difficult to discern. In discussing the most unusual of the window scenes - the presentation of the fish - Emile Mâle suggested what may be the safest explanation for the unusual character of this scene in particular and, by implication, of the window recension in general. Since the presentation of the fish did not figure in any textual source known to Mâle, he proposed that the scene and the cycle must depend on a lost written version. ${ }^{18}$ The results of the present study suggest that Mâle's explanation is too simple, and that the assumption behind it that pictorial narratives are essentially texts translated into visible form is too simplistic, at least for the first half of the thirteenth century. Rather than visualizing the images of literary language, the most distinctive scenes of the Theophilus window cycle seem to depict actual social ceremonies common in the thirteenth century, ceremonies that, since they were meant to be seen rather than read, were particularly suitable as source material for visual narratives. Further, the sense of immediacy gained through the inclusion of such references to contemporary social situations and rituals enabled the window cycle to capitalize on the ability of the Theophilus legend to teach its moral lesson in a direct manner by underlining its relevance for thirteenth-century observers.

The notion of staging portions of the Theophilus legend as a contemporary event was not an invention of the thirteenth-century window designers. Both Emile Mâle and Meyer Schapiro have analyzed the same practice in the three-part cycle of the twelfth-century relief from Souillac, where the scene of the sealing of the pact between Theophilus and the devil (Fig. 6) takes the form of the ceremony through which homage was pledged to an overlord. ${ }^{19}$ Here, Theophilus confronts the devil, who clasps the hands of his new vassal within his own - a composition which remained standard for this episode in all media during the thirteenth century (cf. Fig. 4b). ${ }^{20}$ In the stained glass

${ }^{18}$ Emile Mâle, L'art réligieux du XIIIe siècle en France (Paris, 1923), p. 261, n. 2.

${ }^{19}$ Emile Mâle, Religious Art in France: The Twelfth Century. A Study of the Origins of Medieval Iconography, an annotated translation of the 1953 French edition of L'art réligieux du XIIe siècle en France, first published in 1922 (Princeton, 1978), pp. 436-37. Schapiro, "Sculptures of Souillac," p. 379.

${ }^{20}$ Thirteenth-century depictions of the rendering of homage in totally secular contexts, such as the well-known seal of Raymond de Montdragon (now in Paris, BN) attest to the continued relationship between this scene and the conventions of secular ritual. See J. Roman, Manuel de sigillographie française (Paris, 1912), p. 138 and pl. I. Roman dated this seal to c. 1200 and cited two others from this period depicting acts of homage in a similar fashion: the seals of Gerard de Saint-Aubert (1194) and Conon de Bethume (1202). The scene also appears in a latethirteenth-century manuscript of the Establissements de Saint Louis (Paris, BN, MS fr. 5899, fol. $83 \mathrm{v}$ ) as a miniature illustrating a discussion of the homage due to an overlord from his vassal. The illustration of this gesture is included in François Garnier, Le language de l'image au moyen âge: Signification et symbolique (Paris, 1982), pp. 206-8. For the history and significance of the 
recension, however, the idea behind the formation of this one Romanesque composition was expanded to embrace several interpolated episodes, specifically those episodes that have parallels neither in the manuscript cycles nor, it would seem, in the written sources.

One such episode is the puzzling scene of the presentation of the fish. Like the clasping of hands, the giving of fish was endowed with considerable significance in twelfth- and thirteenth-century secular ceremony. Feudal obligations were frequently paid in fish. ${ }^{21}$ For example, the charter of the commune at Beauvais, confirmed by the king in 1144 and again in 1182 , granted the bishop the authority to take a horse from the commune in order to send a fish to his overlord, the king. ${ }^{22}$ In 1210 the chapter of the cathedral of Mantes agreed that the abbey of Saint-Victor should receive the first salmon that was caught in the Gard each year. ${ }^{23}$ In 1220 new vassals of the archbishop of Tarentaise were required to offer him "duas magnas truitas" as symbols of fealty. ${ }^{24}$ Finally, in an account of its expenses for 1260 , the commune of Beauvais lists the cost of fish to be presented as gifts to the king of England. ${ }^{25}$ Thus, the presentation of a fish to Theophilus as depicted in the window cycle (Figs. 2 and $3 \mathrm{~b}$ ) was an appropriate emblem of his

symbolic ritual itself, which can be traced to the seventh or eighth century, see the fascinating study of Jacques Le Goff, "Les gestes symboliques dans la vie sociale: Les gestes de la vassalité," Simboli e simbologia nell'alto Medioevo, Settimane di studio del Centro italiano sull'alto medioevo 23 (Spoleto, 1976), pp. 679-779 (especially pp. 682-88).

${ }^{21}$ Fishing itself was carefully regulated. Streams and their contents like land and its products had beneficiaries. Richard I of England had the right to all the lamprey taken from the waters of Le Mans, a privilege he ceded to the monks of Saint-Croix in Bordeaux. See Roger Grand, L'agriculture au moyen âge (Paris, 1950), p. 544, whose source is a text cited in du Cange, Glossarium mediae et infimae Latinitatis, 4 (Paris, 1845), 19, "lampragium". I am grateful to Meredith Lillich for drawing this reference to my attention. The bishop of Beauvais, whose domain was situated on the route over which fish were transported from the northwest coast of France to Paris, had the privilege of choosing fish for his own table from the shipments that passed through Beauvais. L. Labande, Histoire de Beauvais et ses institutions communales jusqu'au commencement du XVe siècle (Paris, 1892), p. 221. See also Grand, L'agriculture, pp. 536-38.

${ }^{22}$ Labande, Histoire de Beauvais, p. 269. The document of 1182 is also transcribed in A. Giry, Documents sur les relations de la royauté avec les villes en France de 1180 à 1314 (Paris, 1885), pp. 6-13: "9. Item, si episcopus Belvacensis nobis pisces aliquando mittere voluerit, unum equm capiet." Philippe and Pierrette Bonnet-Laborderie, Cathédrale St.-Pierre de Beauvais: Un vitrail du XIIIe siècle. Le miracle de Théophile (Beauvais, 1975), p. 12, suggested some sort of relationship between what they call the "droit sur le poisson" and the Theophilus window at Beauvais.

${ }^{23}$ A. Cassan, Statistique de l'arrondissement de Mantes (Mantes, 1833), p. 24: . . "salmonem illum qui in bocquio de coppepes primo capitu singulis annis."

${ }^{24}$ Grand, L'agriculture, p. 543. The document is transcribed in Gallia Christiana, 12, Instrumenta, col. 389. For the rendering of fish as a symbolic gesture of feudal investiture see Le Goff "Les gestes symboliques," pp. 693-95, 771-74.

${ }^{25}$ Paris, Archives Nationales, J385, as cited in Labande, Histoire de Beauvais, p. 287. The presentation of gifts to visiting dignitaries became quite a financial burden to other communes during the thirteenth century. Eventually a limitation was imposed, restricting such offerings to cups or flasks of wine and, notably, eliminating the fish which had often been included among them. See William Jordan, Louis IX and the Challenge of the Crusade (Princeton, 1979), pp. 151-52. 
devilish reinstatement as vidame of the bishop. ${ }^{26}$ Thirteenth-century observers would have understood the acceptance of fish as a part of the duties and privileges of Theophilus's position, whether the fish were taken from the waters of the episcopal domain, presented as tribute from a dependent to a superior, or offered as a diplomatic gesture of good will.

It may be a testimony to the strength of the glass recension, and its seeming independence from any specific textual model, that this most curious of its scenes was inserted into a manuscript cycle of the second half of the thirteenth century illustrating the text of Gautier de Coincy's poetic version of the Theophilus miracle (Besançon, Bibliothèque municipale, MS 551). ${ }^{27}$ Most of the miniatures in this manuscript, which is more copiously illustrated than most manuscripts of this text, ${ }^{28}$ reproduce episodes that are described in the poem and that do not form part of window cycles. This is not true of the miniature in which Theophilus is presented with a fish (fol. 9r: Fig. 7), here placed, as in many of the windows (Fig. 2), on a platter. ${ }^{29}$ Perhaps this scene was incorporated to represent a general situation de-

${ }^{26}$ The interpretation of the fish in this scene as a symbol of Christ has led students of particular Theophilus windows to propose allegorical interpretations of this scene. For Etienne Hucher the presence of the fish at Le Mans "peut faire allusion à Jésus-Christ que Théophile trahit en ce moment; on sait que ce symbolisme était très-répandu au XIIIe siècle" (Calques des vitraux peints de la cathédrale du Mans [Paris, 1864], unnumbered pages). Marsat wondered if the fish at Troyes was the symbol for the Eucharist (Cathédrale de Troyes, p. 64).

${ }^{27}$ The rich illustration of this unfinished manuscript is unstudied, but the text is discussed in Arlette Ducrot-Granderye, "Etudes sur les Miracles de Nostre Dame de Gautier de Coincy," Annales Academiae Scientiarum Fennicae, Series B, 25/2 (1932), 51-54. She dates the script to the very end of the thirteenth or the beginning of the fourteenth century and on paleographic evidence locates the place of production as southern France or Italy. See also A. Castan, Catalogue générale des manuscrits des bibliothèques publiques de France, Départements, 32: Besançon (Paris, 1897), pp. 318-19, where the book is assigned to French production and dated to the middle of the thirteenth century. The style of the illustrations argues for execution in northern France in the second half of the thirteenth century. Twenty-six scenes illustrate the Theophilus legend (four are illustrated in Garnier, Le langage de l'image, figs. 88-91), and a gap in the text (after fol. 15r) suggests that one of the folios in this section has been lost. Based on my study of the Theophilus cycle in this manuscript (which betrays a particularly fascinating relationship between image and text), it seems clear that the entire program of illustration deserves a full study, a subject to which I hope to return.

${ }^{28}$ Ducrot-Granderye, "Etudes," lists all extant manuscripts known to her that contain all or part of Gautier de Coincy's miracle and indicates whether or not they contain illustrations. In most cases illustration is restricted to a single scene in a historiated initial at the beginning of the text of each miracle. I discovered only three thirteenth-century narrative cycles (Paris, BN, MSS fr. 1613, 1533, and 22928) in addition to that of the Besançon manuscript. The most extensive of these contains but four episodes. For their contents see Appendix B, nos. 9-11.

${ }^{29}$ There is also a scene of Theophilus distributing alms (fol. 10v), but its context and meaning are totally distinct from the similar composition in the windows. In Gautier de Coincy's version of the miracle, Theophilus hoards his money until his repentance, at which point he begins to distribute it. In the miniature an apparition of Christ inspires Theophilus to give away his money, whereas in the windows the devil is included as the force behind what is clearly to be interpreted as hypocritical activity. 
scribed nearby in the poem: soon after he is returned to power, Theophilus is admonished by the Jewish sorcerer to make an ostentatious display of the wealth he has gained through his evil alliance, by dressing well and eating well, by riding exquisite horses. ${ }^{30}$ But the text does not mention fish, the reception of feudal obligations, or diplomatic gifts. Perhaps the author of this manuscript cycle was familiar with Theophilus windows and drew this scene from one of them to stand for Theophilus's enjoyment of the wealth that had accompanied his return to power.

The ceremonial presentation of a fish is only one of several scenes in Theophilus windows that depict the reinstated vidame executing his administrative duties. In another he distributes alms (Fig. 1). A third scene (Figs. 3a and 4a), in which Theophilus supervises the construction of a church, would have been even more familiar to thirteenth-century worshipers, since in many cases the church around them would still have been under construction. Taken together, these interpolated glimpses of Theophilus's life after the sinister pact were, I would argue, intended to convince the viewers of the relevance of the legend to their own lives. In each an elegantly posed Theophilus brandishes his regained power by displaying and using his wealth in terms readily understandable to thirteenth-century observers, especially those who wielded secular power. In each his actions appear to be pious, but since they are all accomplished through an alliance with the devil, they reminded the viewer that generosity and outward piety do not always indicate inner virtue; appearance is not always reality. As if to underscore this moral, the devil is carefully included as the source of Theophilus's munificence in the distribution of alms (Fig. 1). ${ }^{31}$

This is not the only point in the narrative of Theophilus windows at which interpolated scenes refer to contemporary practice in an attempt to further the didactic efficacy of the cycle. At the opposite extreme from his elegant grandeur and generosity while a servant of the devil is Theophilus's humiliation while stripped and kneeling to await punishment at the hands of his bishop (Fig. 5b), an episode unique to the glass recension. Like the donation of the fish and the sealing of the pact, this scene is staged as a ritualized

${ }^{30}$ Lines $496 \mathrm{ff}$. in Koenig's edition of the text. It is tempting to speculate that Gautier de Coincy could have been inspired by the Theophilus window recension to include this exhortation in his version of the miracle. The Theophilus window at Laon, at c. 1215, clearly predates Gautier's poem, which was begun in 1218. Laon, after all, is not far from Vic-sur-Aisne, where Gautier composed his poem. For the date of the poem see Koenig, Les miracles, pp. xviii-xxx. For the date of the window at Laon see Appendix A, no. 1.

${ }^{31}$ The implications of this scene are rendered most clearly in the composition at Beauvais, where the devil, cut from a piece of blue glass that is slightly lighter in tonality than the blue ground against which it is set, appears ambiguous, as if invisible to the recipients of the alms, but clearly behind Theophilus's actions. At Le Mans (Virgin Chapel) a devil appears behind Theophilus as he receives the fish. Of course, the use of this visual device to indicate evil inspiration is common in Gothic painting. It often appears, for instance, when Saul is moved to abuse David (e.g., New York, Morgan Library, MS M 638, fols. 26r, 29v, 30v, and 31r). 
ceremony. It is strikingly reminiscent of descriptions of public penances enacted by high secular officials who were guilty of serious sins against God or, more likely, against the church and its jurisdiction..$^{32}$

The most famous instances of penitential scourging are associated with kings. Henry II of England submitted to it in 1174 when, at the close of his pilgrimage to Becket's tomb, he walked into Canterbury barefoot, threw himself before the tomb, and was scourged in succession by the bishops, abbots, and monks present. ${ }^{33}$ Saint Louis accepted scourging with relish as part of his penance for the failure of the seventh crusade, but his action is actually closer to self-mortification than to prescribed punishment. ${ }^{34}$ Flagellation as public penance, however, was not restricted to the monarchy. Less ostentatious examples from the first half of the thirteenth century involving lesser nobility provide a more focused context for this interpolated scene in Theophilus windows.

Raymond IV of Toulouse, for example, anxious for political reasons in 1209 to reconcile himself with the church, publicly confessed his sins, was scourged by the papal legate, and then took the cross against the Albigensians. ${ }^{35}$ Robert de Lisle, bailiff of Gerberoy, was declared guilty in 1247 of usurping power that properly belonged to the local church. His penitential sentence required him to walk from the marketplace to the church in Gerberoy with bare feet and shoulders, carrying a switch in his hand. When he arrived, he was to humble himself before the assembled clergy, promise never again to violate the rights of the church, and receive whatever discipline the clerics wished to inflict upon him. He was further required to repeat the spectacle at the cathedral of Beauvais. ${ }^{36}$ Another example from the 1240s, equally as public and complex and equally reminiscent of the

${ }^{32}$ For a general discussion of penance in the twelfth and thirteenth centuries see $\mathrm{O}$. D. Watkins, A History of Penance (London, 1920), especially volume 2, pp. 723-49; and C. Vogel, Le pécheur et la pénitence au moyen âge (Paris, 1969). It should be emphasized that private, auricular confession (codified by the Fourth Lateran Council in 1215) was the most common form of penance in the thirteenth century. Public penance involving scourging seems to have been performed most often by nobility and royalty.

${ }^{33}$ For an eloquent account of this well-known penance see P. Schaff, History of the Christian Church, 5/1 (New York, 1907), 146-47.

${ }^{34}$ See Jordan, Louis IX, pp. 127-28, with references to the primary sources. A scene of Louis's submission to flagellation, not unlike the composition in the Theophilus windows, formed a part of a fourteenth-century cycle of his life in a window at Saint-Denis, now known only through the engravings of Bernard de Montfaucon, Monuments de la monarchie françoise, 2 (Paris, 1730), pl. XXIII.

${ }^{35}$ Joseph R. Strayer, The Albigensian Crusade (New York, 1971), pp. 56-60. Public scourging was also one of the penances imposed on heretics during the crusade Raymond agreed to join. See T. de Cauzons, Histoire de l'Inquisition en France, 2 (Paris, 1912), 299-303; and H. C. Lea, A History of the Inquisition in the Middle Ages, 1 (New York, 1922), 463-65.

${ }^{36}$ L'abbé Delettre, Histoire du diocèse de Beauvais, 2 (Beauvais, 1843), 298-99; and J. Pillet, Histoire du château et de la ville de Gerberoy (Rouen, 1679), pp. 178-79 and 346-47, where the original document outlining the sentence is transcribed. 
composition in the Theophilus windows, is the penance required of Robert de Villette and Guilaume Perier, who had murdered the prior of Juziers. Like Robert de Lisle, they processed publicly with bare feet to churches - in their case not only the site of their crime but also all the cathedral churches of the archdiocese of Rouen as well as that of Paris - and presented themselves to the local clergy, prepared to be scourged for their $\sin .^{37}$

The author of the iconographic program adopted by the thirteenthcentury glass painters appears, therefore, to have selected for didactic purposes certain scenes that are absent from the written sources. By interpolating episodes staged as easily recognizable contemporary events, he furthered the ability of the legend to instruct. Those who viewed the windows could identify with the once righteous man who had erred, and they would thus be encouraged to avoid the pride and hypocrisy which led to and characterized his tenure with the devil. Simply stated, the window became a visual sermon on a monumental scale, one which needed no identifying inscriptions or accompanying explanations to be understood. Such a homiletic design may seem particularly appropriate for windows, which, unlike manuscripts, were for public rather than private consumption. But the use of these interpolated compositions was restricted neither to windows nor to monumental art at this time. Their place in Theophilus windows is best evaluated within the context of a broader didactic movement of the first half of the thirteenth century, a movement which relied on pictures to teach moral lessons. Its best known example is found not in windows but in books - the massive program of the Bible moralisée. ${ }^{38}$

${ }^{37}$ Cassan, Statistique, pp. 253-54; and Levrier, "Mémoires chronologiques pour servir à l'histoire du Vexin et du Pinserais," Paris, Bib. Nat., Collection du Vexin, MS 7, pp. 578-79. I am grateful to Meredith Lillich for bringing these references to my attention.

${ }^{38}$ Portions of four Bibles moralisées have survived from this period: (1) Vienna, Österreichische Nationalbibliothek, MS 1179; (2) Vienna, Österreichische Nationalbibliothek, MS 2554; (3) three volumes in Toledo, Biblioteca del Cabildo, MSS 1-3, of which the final folios are in New York, Morgan Library, MS M 240; and (4) a Bible divided between Oxford, Bodleian Library, MS 270b; Paris, BN, MS lat. 11560; and London, British Library, Harley MSS 1526-27. The last of these is reproduced in its entirety, along with selected folios from the others, in Alexandre de Laborde, La Bible moralisée conservée à Oxford, Paris, et Londres, 5 vols. of plates (Paris, 1911-21). For the most thorough study of these manuscripts see Reiner Haussherr, "Sensus litteralis und sensus spiritualis in der Bible Moralisée," Frümittelalterliche Studien 6 (1972), 356-80; idem, Bible moralisée: Faksimile-Ausgabe im Originalformat des Codex Vindobonensis 2554 der Österreichischen Nationalbibliothek, 2 (Graz, 1973); Robert Branner, Manuscript Painting in Paris during the Reign of Saint Louis (Berkeley, 1977), pp. 36-65; and idem, "Saint Louis et l'enluminure parisienne au XIIIe siècle," in Septième centennaire de la mort de Saint Louis, Actes des colloques de Royaumont et de Paris, mai 1970 (Paris, 1977), pp. 77-78. There is no consensus on the exact dates of these four Bibles. Haussherr dates the two Vienna Bibles to c. 1220 and the Toledo Bible to c. 1230. Branner believed that the Vienna Bibles could have been somewhat earlier, between c. 1212 and 1225. He dated the Toledo Bible to c. 1225-30 and the Oxford/Paris/London Bible to c. 1235-45. Although there are later Bibles moralisées based on the programs of the four earliest examples, all of them postdate the thirteenth century. They are discussed in the studies of Haussherr cited above. 
When the vast interpretive programs of the Bibles moralisées were developed to elucidate or interpret selected episodes from the Scriptures, ${ }^{39}$ some of the same scenes that were interpolated into the Theophilus windows were used to carry the visual burden of the moral in the manuscripts. Although brief summaries of biblical narratives paired with epigrammatic moralizations form the written text of these books, their primary concern is with pictures. Because of their similar dependence on pictorial language to further a didactic program, a comparison between Theophilus windows and the Bibles moralisées naturally suggests itself.

The familiar scene of homage, depicting the devil clasping the joined hands of a newly acquired vassal, appears several times in the Bibles. In one instance (Österreichische Nationalbibliothek, MS 1179, fol. 51r: Fig. 8) it is juxtaposed with a scene showing Moses excluding those with hernias from the priesthood (Leviticus 21.20), an act which, as the commentary explains, signifies Christ's exclusion from the church of those who reject its sacraments and offer themselves instead to the devil. In the same Bible similar depictions of homage to the devil are used to interpret the biblical episodes of Soloman worshiping the idols of his pagan wives (3 Kings 11.1-10; fol. $115 \mathrm{r}$ ) and the Jews' desertion of their king, Rehoboam, to follow the wicked Jeroboam (1 Kings 12.16-20; fol. 116r). ${ }^{40}$

Of the compositions common to the Theophilus windows and Bibles moralisées, the scene of penitential scourging appears most frequently in the manuscripts. ${ }^{41}$ This climactic event in the public ritual of retribution served as a pictogram for the concept of penance, appearing regularly whenever a biblical episode evoked this timely Christian virtue. In the most straightforward example (ÖNB 1179, fol. 106r; ÖNB 2554, fol. 46r: Fig. 9), the scene is used to interpret David's remorse over his part in the death of Uriah and his fervent prayer that its tragic consequence, the impending death of his own son, might be avoided (2 Samuel 12.13, 16). In another instance (Bodleian Library, MS 270b, fol. 14r) it is coupled with a depiction of baptism to form a composite composition representing the moralization of the covenant of circumcision (Genesis 17.10-12, 26-27). The paired images

${ }^{39}$ Although there are correspondences between the programs of the four extant thirteenthcentury manuscripts, they are by no means identical, either textually or visually. The choice of biblical episodes and the moralizations which accompany them vary. The Toledo and Oxford/ Paris/London Bibles are the most closely related, often choosing the same images to elucidate the same scriptural episodes even if the textual commentaries vary somewhat. For the relationship between these four manuscripts see the studies by Haussherr and Branner cited in the previous note.

${ }^{40}$ The scene appears twice in the Oxford/Paris/London Bible: Bodl. 270b, fols. 166r and 205v. The latter example is especially interesting, since it includes a Jewish intermediary between the devil and his new vassal in a composition reminiscent of the scene from the Theophilus window at Laon.

${ }^{41}$ It is used twenty-seven times in the Toledo Bible and twenty-three times in the Oxford/ Paris/London Bible. 
juxtapose a central ritual of the old order with two sacraments of the new. In another Bible (ÖNB 1179, fol. 43r: Fig. 10) the depiction of penitential scourging is used to interpret the Mosaic admonition to wash the flesh of a sacrificed animal (Leviticus 1.9). In this case, however, the picture commands an integrity equal to that of the word in establishing the moral. Whereas the moralizing text - "Hoc quod carnes laverunt significat ablutionem baptismi" - associates the Old Testament ceremony with baptism, the moralizing image equates this ritual of the old order with another Christian sacrament that purifies the righteous - penitential confession and scourging. The image thereby adds a related but separate interpretation instead of reproducing the meaning of the text, as was the case in the previously cited examples. ${ }^{42}$

The most revealing comparisons between interpolated scenes from Theophilus windows and interpretive images in the Bibles moralisées concern the ceremonial presentation of a fish to a powerful person. ${ }^{43}$ This most curious scene from the glass recension is more unusual than either scenes of homage or depictions of penitential scourging in thirteenth-century narrative art, but it does appear with some frequency in the Bibles moralisées. The simplest of the morals represented by this composition has to do with God's

42 The frequent choice of penitential scourging and baptism to stand for the new covenant in the Bibles moralisées deserves further study. (Another example can be seen in ÖNB 2554, fol. 29r.) The importance of penance could be related to the proceedings of the Fourth Lateran Council in 1215, since the programs of the manuscripts are contemporary or postdate it (see n. 34 above), but, curiously, the compositions evoke a public ceremony whereas the council emphasized private auricular confession. Perhaps the choice is more closely related to the general didactic stance and specific intended audience of the manuscripts. Penitential scourging was associated with aristocratic sins, and the Bibles moralisées were clearly made for aristocratic patrons. I will argue below that Theophilus windows were made to address a similar audience, providing yet another point of comparison between Bibles and windows and another explanation for their use of a common pictorial language.

${ }^{43}$ It is important to distinguish between those instances, common in thirteenth-century visual narratives in all media, in which a fish appears on a dinner table or is served to those seated at a table ready to eat (i.e., instances in which the fish represents nourishment) and those in which the fish is an emblem of worldly delights or feudal tribute. Fish are used in both contexts in the Bibles moralisées. Fish appear on Job's table after he has regained his prosperity (Job 42.11; ÖNB 1179 , fol. 161r) and are served to a dining figure in the parallel interpretive image. In an interesting variation on the use of the fish as an emblem of nutrition, the visualization of Mordochai's adoption of Esther shows the father offering a fish on a platter to his newly acquired daughter (Esther 2.5-7; ÖNB 1179, fol. 186r). In the moralizing composition that accompanies it, Ecclesia holds a chalice, paralleling spiritual nourishment with the temporal sustenance of the fish. In one instance, where the fish is offered to a diner by the devil (ÖNB 1179 , fol. 145r), and in another, where although the recipient is seated at a table, the fish is offered along with other worldly delights and appears to symbolize with them an appetite for wealth rather than simply for food (Bodl. 270b, fol. 21v), the significance of the scene is close to that of the more ceremonial presentations discussed here. In all cases it is worth noting that the association of the fish with worldly or temporal concerns is constant, regardless of the exact context. 
separation of the waters above and below the firmament (Genesis 1.7-8) in two of the Bibles (Toledo, Biblioteca del Cabildo, MS 1, fol. 2r; Bodl. 270b, fol. 2r). The texts of the moral vary, but their message is the same. In one manuscript the biblical event signifies the separation of good from evil, in the other spiritual from wordly delights. An identical, two-register medallion accompanies the text in both manuscripts (Fig. 11). A good bishop, distributing clothing to a beggar, is contrasted with a bad bishop, surrounded by emblems of his wealth. Among his worldly delights is a fish presented on a platter in a composition strikingly similar to those in Theophilus windows (cf. Fig. 2), and bearing the same significance. The evil man takes advantage of his powerful position to accrue wealth. ${ }^{44}$

The association of the presentation of a fish with a preference for the worldly rewards of power instead of and at the expense of the spiritual rewards of Christian virtue continues in each of its appearances in the Bibles. ${ }^{45}$ The plague of gnats which attacked the eyes of the Egyptians (Exodus 8.16-17), for example, is equated in the text with offerings of rich gifts which blind bad kings and prelates (ÖNB 2554, fol. 19v). In the accompanying image (Fig. 12) a fish on a platter is one of the worldly temptations held before the transgressors. Although Potiphar's wife, who tempts the virtuous Joseph (Genesis 39.7, 11-12), is interpreted in the text of one Bible moralisée (ÖNB 2554, fol. 8v) as the snake who tempted Adam and who will tempt each good man in his turn, a snake is not the most salient tempter of the seated noble in the adjacent image (Fig. 13). In the foreground are two attending figures who offer worldly wealth - a ring and a fish. Finally, in two of the manuscripts (Toledo 3, fol. 189r; British Library, MS Harley 1527, fol. 144r) the pictorial moral (Fig. 14) of the destruction of Babylon (Apocalypse 18.7) portrays rich gifts, including a fish, being offered once again to a bishop, in this case accompanied by a king. Here the meaning of the composition is particularly close to its significance in Theophilus windows. The moralizing text explains that just as worldly efflorescence did not save the city of Babylon from eventual destruction, sinners who glorify themselves in the world with positions of authority and

\footnotetext{
${ }^{44}$ The juxtaposition in the same composition of an ecclesiastical figure who receives worldly wealth (including a fish) with one who distributes it is a relatively popular device in the Bibles, appearing as well in Toledo 3, fol. 146r, and Harley 1527, fol. 46r. In the former instance, the scene elucidates the biblical identification of money as the root of all evil (1 Timothy 6.10-11) and in the latter the parable of the wise and foolish virgins (Matthew 25.1-12).

45 The following is a list of the fifteen instances in which the presentation of a fish appears as a moralizing image in extant Bibles moralisées: ÖNB 1179, fol. 215r; ÖNB 2554, fol. 8v; ÖNB 2554, fol. 19v; Toledo 1, fol. 2r, and Bodl. 270b, fol. 2r; Toledo 1, fol. 74r, and Bodl. 270b, fol. 82r; Toledo 1, fol. 128r, and Bodl. 270b, fol. 160r; Toledo 1, fol. 158r; and Bodl. 270b, fol. 190r; Toledo 3, fol. 55r; Toledo 3, fol. 86r; Toledo 3, fol. 94r; Toledo 3, fol. 146r; Toledo 3, fol. 189r, and Harley 1527, fol. 144v; Bodl. 270b, fol. 21v; Lat. 11560, fol. 176r; Harley 1527, fol. $46 \mathrm{r}$.
} 
attendant riches will be subjected by God to eternal punishment because they did not repent. It is interesting that the artist bypassed the opportunity to depict the justly deserved torment of the sinners - always a favorite subject of medieval artists - and chose instead to show figures who like Theophilus appear to be virtuous by the nature of their temporal status, but are actually hypocrites. By doing so he represents the same dichotomy between internal motivation and external appearance (cf. Fig. 1) which characterizes the didactic interludes in the window cycles between Theophilus's reinstatement and his repentance. Again, like the glass painter, by staging the moral as a scene drawn from contemporary social custom, he has increased its ability to teach its lesson to a contemporary audience.

In the early thirteenth century the increasing popularity of the legend of Theophilus as a subject for the monumental decoration of churches appears to have led to the development of a distinctive narrative cycle for use in stained glass windows. Comparison with the cycles used in contemporary manuscripts shows that the window recension was constructed with a particular didactic emphasis. To this end, certain scenes that seem to have no parallels in written versions of the legend and that were staged in the guise of contemporary social custom and ritual were interpolated into the glass recension. The closest parallel for the iconographic strategy revealed in Theophilus windows is found in the program of interpretive imagery used in the four extant thirteenth-century Bibles moralisées. Comparison between the Bibles and the windows extends to their use of the same emblematic compositions, revealing a reliance on the same pictorial language to convey their moral messages. Furthermore, the development of comparable didactic programs for Theophilus windows and Bibles moralisées occurred simultaneously in the first quarter of the thirteenth century and remained popular only to the middle of that same century. ${ }^{46}$

Two further observations may be made. The first concerns the question of audience. By arguing for the didactic structure of the Theophilus window recension, I do not mean to imply any sort of popularizing movement. This was in no sense an attempt to educate an unlettered multitude. The full significance of the windows seems to have been directed at the small group of wealthy and powerful men who, like Theophilus or like Robert de Lisle, wielded temporal, secular authority. The story, after all, concerns the sort of

\footnotetext{
${ }^{46}$ Actually the interpolated episodes in Theophilus windows may have fallen out of favor even before its use as a subject began to decline. The legend appears twice, in each instance filling an entire lancet, in the mid-thirteenth-century glazing of the ambulatory clerestory at Le Mans (see Appendix A, nos. 7 and 8), but the didactic compositions that characterize earlier windows and which were the subject of this study do not appear in these admittedly abbreviated cycles. Furthermore, in both cases the Theophilus legend is not highlighted as an independent subject, but is instead part of a larger iconographic whole devoted to the glorification of the Virgin rather than the teaching of a moral lesson.
} 
sin whose commission was a privilege of this class alone, and the windows, as I hope to have demonstrated, used its symbolic rituals to convey a focused message about hypocrisy and the misuse of power. ${ }^{47}$ Another miracle of the Virgin might have been singled out for such widespread treatment if the concern had been to address other or broader audiences with more generalized moral messages. Similarly, the lavishly illustrated Bibles moralisées, employing some of the same pictorial morals, were created for aristocrats and royalty. ${ }^{48}$

A second observation about these parallel and contemporary developments concerns their relative rarity. Didactic structure does not seem to have been as common an iconographic strategy in High Gothic visual narrative as might at first be imagined. The subject matter of architectural decoration in this period tended to be organized historically or conceptually more than didactically, so as to express abstract doctrine rather than straightforward moral messages. Further studies of other window narratives might reveal parallel instances of didactic structure, but I believe it is unlikely that straightforward moralizing will emerge as a common narrative mode in thirteenth-century monumental art.

Some churchmen, however, were clearly concerned with the dichotomy between appearance and reality in the lives of high officials. Perhaps they were using Theophilus windows as visual sermons not only to warn men in authority of the consequences of hypocrisy but also to show them its remedy. ${ }^{49}$ Because the artists commanded a pictorial language that allowed

${ }^{47}$ The evidence of comparative material confirms this interpretation. Meyer Schapiro proposed that the Theophilus relief of Souillac was carved for a comparable audience ("Sculptures of Souillac," pp. 383-87). Le Goff argues that the actual "rituel symbolique de la vassalité" which is the source for a scene shared by Souillac (Fig. 6) and the windows (Fig. 4b) was equally as dependent on recognition by a select audience ("Les gestes symboliques," pp. 746-47). What is more, Koenig suggests that Gautier de Coincy's poem on the same subject was prepared during the first quarter of the thirteenth century for a readership of similar aristocratic complexion (Les Miracles de Nostre Dame, pp. xxvi-xxvii).

${ }^{48}$ See Branner, "Saint Louis et l'enluminure," p. 78; and Haussherr, "Sensus literalis," pp. $364-65$.

${ }^{49}$ A comparison between Theophilus windows - their narrative structure and their characteristic compositions - and the structure and imagery of contemporary sermons would be a productive area for future research. My cursory examination of the sermon literature revealed no exact parallels with the interpolated scenes of the window cycles, but it would not be surprising to find them. By the middle of the thirteenth century, preachers could have been familiar with the Theophilus windows, which were presumably common in the Virgin Chapels of large churches. For the use of the legend in early sermons see n. 6 above. See as well Brian S. Lee, "'This is no fable': Historical Residues in Two Medieval Exempla," Speculum 56 (1981) 728-60 (Theophilus sermons are cited on p. 728 and n. 1), where the study of the mixture of history and legend in medieval sermons might be compared to the mixture of legend and contemporary social ritual in Theophilus windows. Both seem to be attempts to make moral messages more believable and persuasive. I am grateful to Kathleen Greenfield for discussing medieval sermons with me and for providing valuable bibliographic information about their study. 
observers to project themselves, or others, into the narrative by means of scenes drawn from their own experience, these glistening homilies were intelligible without inscriptions or commentary of any kind. This feature, evident alike in the Theophilus windows and in contemporary Bibles moralisées, goes a long way toward explaining the imagery of the windows and its significance for the thirteenth-century audience.

\section{SWARThMore College}

\section{Appendix A}

\section{Theophilus Cycles in Thirteenth-Century French Stained Glass Windows}

Many of the windows listed below (e.g. nos. 2, 3, 4, 6, and 9) have not been preserved in their entirety. The chart showing the content of the cycles does not include modern panels made in the nineteenth and twentieth centuries, since the relationship of these modern panels to the original iconographic composition is problematical at best. Furthermore, it is difficult to determine whether or not in their current installation these Theophilus windows reproduce the original, thirteenthcentury order of the scenes which comprise them. Window designs, often modular in nature, allow transpositions of panels from one restoration and installation to the next. Because these two problems make reconstructing the original order of the narrative in these windows virtually impossible, or at least largely hypothetical, the chart simply indicates the inclusion of a scene in the current state of the windows.

I have not included the thirteenth-century Theophilus windows of Angers, Gercy, or Dreux, since limited preservation (only a single scene survives in the first two instances and only two in the third) renders them essentially useless for a study of the composition of narrative cycles. The scene surviving at Angers (a much damaged depiction of the presentation of the fish that appears to have been distributed over two panels in the window) is now installed near the bottom of the first window west of the crossing on the north side of the nave (panels $2 b-2 c$ of window N-14 in Jane Hayward and Louis Grodecki, "Les vitraux de la cathédrale d'Angers," Bulletin monumentale 124 [1966], 26, where the Theophilus scene is identified as a depiction of Christ in Majesty, fragments of which seem to surround it). Presumably this is the scene from a Theophilus window noted at Angers by Jean Lafond, "The Stained Glass Decoration of Lincoln Cathedral in the Thirteenth Century," Archaeological Journal 103 (1946), 133, n. 28. For the Gercy panel, which depicts the sealing of the pact, see Louis Grodecki, Vitraux de France, exhibition catalogue, Musée des arts décoratifs (Paris, 1953), pp. 51-52; and idem, in Cathédrales, exhibition catalogue, Musée du Louvre (Paris, 1962), entry 152. For the Dreux panels, which depict the Virgin regaining and then returning the pact, see Les vitraux du Centre et des pays de la Loire, Corpus Vitrearum Medii Aevi, France, Recensement des vitraux anciens de la France 2 (Paris, 1981), p. 67.

\section{LAON, Eastern Terminal Wall, c. 1215}

Florens Deuchler, Der Ingeborgpsalter (Berlin, 1967), pp. 149-60. Louis Grodecki, in L'Europe gothique, exhibition catalogue, Musée du Louvre (Paris, 1968), pp. 115-16; 
idem, et al., Les vitraux de Paris, de la region parisienne, de la Picardie, et du Nord-Pas-deCalais, Corpus Vitrearum Medii Aevi, France, Recensement des vitraux anciens de la France 1 (Paris, 1978), pp. 162-63. Although this window has been restored, its iconography is reliable, and in its current state it seems to represent a complete cycle. Moreover, the nature of the design makes it reasonably certain that the current installation reproduces the original order of the scenes. Although there is agreement that this is the earliest preserved Theophilus window, its exact date is controversial. Deuchler (p. 157), finding awkwardness in the design of the window as now installed, and arguing that the combination of the legend of Theophilus with scenes from the life of Saint Stephen is unusual, maintains that the window(s) must have been made before the reconstruction of the choir at Laon and subsequently reused in its present installation. He proposes, therefore, a date before 1205 for the original window. Grodecki ("Le Psautier de la Reine Ingeborg et ses problèmes," Revue de l'art 5 [1969], 73-78) argued, on the other hand, that all the windows now in the eastern terminal wall were produced for the glazing of the reconstructed choir, and he therefore dated the Theophilus window to c. 1210-15. Since the glazing of the eastern terminal wall is so unified, both in design and iconography, Grodecki's position is clearly the more reasonable one. The combination of more than one subject in a single lancet is by no means unique to Laon.

\section{Le Mans, Virgin Chapel, c. 1235}

Etienne Hucher, Calques des vitraux peints de la cathédrale du Mans (Paris, 1864). Louis Grodecki, "Les vitraux de la cathédrale du Mans," Congrès archéologique de France 119 (1961), 80, n. 3. This window is heavily restored. Some panels are entirely modern, and it is improbable that they reproduce lost originals, since the scenes they depict were not part of the window as described by Hucher in 1864 before its restoration. At the suggestion of Catherine Brisac I examined the original drawings made for Hucher in the 1840s (now in the Musée du Mans), not all of which were reproduced in his publication, to see if the remains of this Theophilus window appear among them. They do not. My catalogue of the episodes from this window is based on the descriptions of Hucher and François de Guilhermy (Paris, BN, nouv. acq. MS fr. 6103 , fols. $99 \mathrm{r}-\mathrm{v}$ ) as well as on my own examination of the window as currently installed.

\section{Auxerre, Virgin Chapel, c. 1235-40}

François de Guilhermy, in Paris. BN, nouv. acq. MS fr. 6095, fols. 691v-692r. L'abbé Bonneau, "Descrıption des verrières de la cathédrale d'Auxerre," Bulletin de la société des sciences historiques et naturelles de l'Yonne 39 (1885), 332-33. Virginia Chieffo Raguin, Stained Glass in Thirteenth-Century Burgundy (Princeton, 1982) pp. 168-70. Entire panels of this window are modern and have not been included in the chart.

\section{Saint-Julien-Du-Sault, Ambulatory Chapei, c. 1250}

Jean Lafond, "Les vitraux de Saint-Julien-du-Sault," Congrès archéologique de France 116 (1958), 366. Lydwine Saulnier, "Les vitraux de Saint-Julien-du-Sault," in Violletle-Duc dans l'Yonne, Les Cahiers des Archives 2 (Auxerre, 1980), pp. 49-53. Raguin, Thirteenth-Century Burgundy, pp. 67-69. Although the window is heavily restored, its iconography seems to be reliable. An interesting problem is introduced by the existence of panels in the Detroit Institute of Art which appear to be from this window. Conclusions about the cycle, therefore, must be tendered with some caution.

\section{Troyes, Choir Clerestory, c. 1245}

Jean Lafond, "Les vitraux de la cathédrale Saint-Pierre de Troyes," Congrès archéologique de France 113 (1955), 46-48. Andre Marsat, in Cathédrale de Troyes: Les 
vitraux (Paris and Troyes, 1977), pp. 63-65. This is a fascinating cycle, containing the only known representation within the Theophilus window recension of the Virgin in supplication before Christ, an explicit indication of her role as intercessor between Man (Theophilus) and God (Christ). In an interesting typological reference, two scenes from Genesis - the Fall and God's reprimand - fill the tracery roses.

6. Beauvais, Virgin Chapel, c. 1245

Philippe and Pierrette Bonnet-Laborderie, Cathédrale Saint-Pierre de Beauvais: Un vitrail de XIIIe siècle. Le miracle dè Théophile (Beauvais, 1975). Michael Watt Cothren, "The Thirteenth and Fourteenth-Century Glazing of the Choir of the Cathedral of Beauvais," Dissertation, Columbia University, 1980, pp. 119-46. The bottom two registers are modern and have not been included in the chart.

7. and 8. Le Mans, Ambulatory Clerestory, c. 1250

See the studies cited in no. 2 above. The tracings of these windows made for Hucher in the 1840 s document that the iconographic disposition was faithfully maintained in the subsequent restoration.

\section{Clerrmont-Ferrand, Chapel of Saint John, c. 1275-85}

Henri du Ranquet, Les vitraux de la cathédrale de Clermont-Ferrand (ClermontFerrand, 1932). This window is heavily restored and includes six rather strange, modern subjects not catalogued here. A careful study of restoration must precede any iconographic conclusions about this unusually late Theophilus window.

See chart on following page. 


\begin{tabular}{|c|c|c|c|c|c|c|c|c|c|c|}
\hline & & 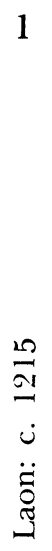 & 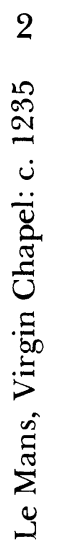 & 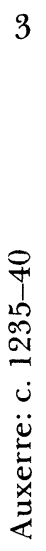 & 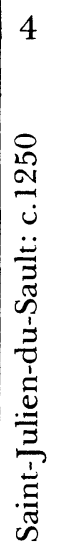 & 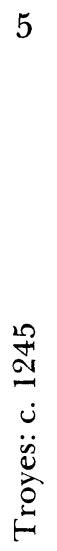 & 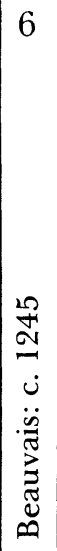 & 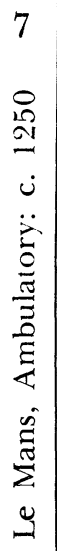 & 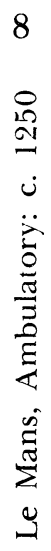 & 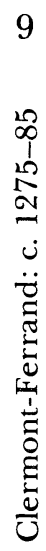 \\
\hline \multirow{9}{*}{ 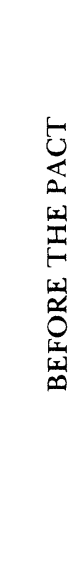 } & Theophilus as Vidame & $?$ & & & & & & & & \\
\hline & Theophilus chosen to be Bishop & $?$ & & & & & & & & \\
\hline & Theophilus refuses office & $?$ & & & & ? & & $?$ & & \\
\hline & Theophilus is dismissed & + & $?$ & & ? & ? & & ? & $?$ & \\
\hline & Theophilus in disgrace & & & & + & & & & & \\
\hline & Devils attack a building & + & & + & + & + & & & & \\
\hline & Theophilus seeks and meets Saladin & + & + & + & & & & & & + \\
\hline & $\begin{array}{l}\text { Theophilus meets the devil: } \\
\text { the pact is negotiated }\end{array}$ & + & & & + & & + & & & \\
\hline & THE PACT IS SEALED & + & + & + & + & + & + & + & + & + \\
\hline \multirow{6}{*}{ 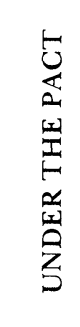 } & Theophilus is reinstated & & $?$ & & & & & & $?$ & \\
\hline & Theophilus receives money & & & + & & & & & & + \\
\hline & Theophilus distributes alms & + & & + & & & + & & & \\
\hline & Theophilus receives a fish & + & + & + & + & + & + & & & \\
\hline & Theophilus is worshiped by the devil & & & & & & & & & \\
\hline & Theophilus builds a church & + & & + & + & & + & & & + \\
\hline \multirow{5}{*}{ 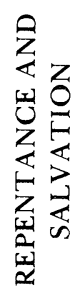 } & Theophilus enters a church & + & $?$ & + & + & & + & & & + \\
\hline & PRAYER TO THE VIRGIN & + & $?$ & + & + & & + & + & & + \\
\hline & The Virgin appears to Theophilus & + & & + & & & + & & & + \\
\hline & THE PACT IS RETRIEVED & + & + & + & + & + & & + & & + \\
\hline & THE PACT IS RETURNED & + & + & + & + & + & + & + & + & + \\
\hline \multirow{5}{*}{ 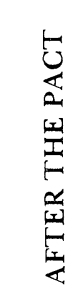 } & The pact is burned & & & & & & & & & \\
\hline & The pact is offered to the Bishop & + & $?$ & + & $?$ & & + & & + & \\
\hline & Theophilus's penance & + & & + & & & + & & & \\
\hline & The Bishop's sermon about Theophilus & + & & & & & + & & & \\
\hline & $\begin{array}{l}\text { Theophilus's funeral and the } \\
\text { ascent of his soul }\end{array}$ & + & & + & & & + & & & \\
\hline
\end{tabular}




\section{APpendix B}

\section{Theophilus Cycles in Thirteenth-Century Manuscripts}

The numbers in the chart indicate the order of the scenes in each manuscript cycle.

1. Munich, Staatsbibliothek, Clm 17401

Miscellany, first half of the thirteenth century (fols. 17v-19v)

J. Damrich, Ein Kunstlerdreiblatt des XIII. Jahrhunderts aus Kloster Scheyern (Strassburg, 1904), pls. iv-vi. Albert Boeckler, Deutsche Buchmalerei vorgotischer Zeit (Königstein im Taunus, 1952), p. 80.

2. London, British Library, Add. MS 49999

Book of Hours, painted by W. de Brailes (Sarum use), first half of the thirteenth century (fols. 32v-44r)

Nigel J. Morgan, Early Gothic Manuscripts, 1: 1190-1250, A Survey of Manuscripts Illuminated in the British Isles 4 (London, Oxford, and New York, 1982), pp. 119-21, illus. 244, with references to the earlier bibliography. The Theophilus series (whose scenes are identified by inscriptions) is part of a long Mariological cycle running through the book, which begins with the life of the Virgin and continues with an anthology of her miracles. The most fascinating feature of this cycle is the insertion of a portrait of the artist at prayer, being blessed by the hand of God (fol. 43r, identified by inscription: "W. de brail q me depeint") between the burning of the pact (fol. 42v) and Theophilus's death (fol. 44r). It seems that the artist seeks to identify himself (optimistically) with the forgiven Theophilus at this moment. The insertion of himself into a religious narrative is not uncharacteristic of de Brailes, who elsewhere (Last Judgment leaf in Cambridge, Fitzwilliam 330) pins his salvation to his role as an artist.

3. Cambridge, Fitzwilliam MS 330

Prefatory Cycle for a Psalter, W. de Brailes, first half of the thirteenth century

Morgan, Early Gothic Manuscripts, pp. 118-19. The cycle here is arranged around a wheel of fortune.

4. Paris, Bibliothèque nationale, MS lat. 238

PSALTER, early thirteenth century (fol. 78v)

Victor Leroquais, Les Psautiers manuscrits latins des bibliothèques publiques de France (Mâcon, 1940-41), 2:38, pl. XLVIII. Harvey Stahl, in The Year 1200, 1: The Exhibition, ed. Konrad Hoffmann (New York, 1970), pp. 245-46.

5. Chantilly, Musée Condé, MS 9

INGEBORG Psalter, c. 1200 (fols. 35v-36r)

Florens Deuchler, Der Ingeborgpsalter (Berlin, 1967), pp. 67-70, pl. XXXI. 
6. London, Lambeth Palace Library, MS 209

De Quincey (Lambeth) Apocalypse, second half of the thirteenth century (fols. 46r-47r)

George Henderson, "Studies in English Manuscript Illumination. Part III: The English Apocalypses, II" Journal of the Warburg and Courtauld Institutes 31 (1968), $129-45$.

7. London, British Library, MS Stowe 17

LiÈGE PSALTER, thirteenth century (fols. 255v-56v)

Judith Oliver, "The Lambert-le-Begué Psalters: A Study in Thirteenth-Century Mosan Illumination," Dissertation, Columbia University, 1976, pp. 299-302, fig. 53. A single historiated initial with a scene from the miracle of Theophilus (usually the return of the pact) often introduces the texts of the Aves poems in these Psalters. Oliver (p. 299) cites eleven examples. Stowe 17 is unusual among them in the depiction of a cycle.

8. Besançon, Bibliothèque municipale, MS 551

Gautier De Coincy, Miracles de Nostre Dame, second half of the thirteenth century (fols. $6 r-18 v$ )

9. Paris, Bibliothèque nationale, MS fr. 1533

Anthology, including Gautier de Coincy's Miracles, second half of the thirteenth century (fols. 37r, 39r, 42r, 262v)

10. Paris, Bibliothèque nationale, MS fr. 1613

GAUTIER DE Coincy, Miracles, second half of the thirteenth century (fols. 1r and 3v)

11. Paris, Bibliothèque nationale, MS fr. 22928

Anthology, including Gautier de Coincy's Miracles, late thirteenth century for this portion, although part of the manuscript seems to have been executed in the fourteenth century (fol. 42r)

These last four cycles are associated with texts of Gautier de Coincy's version of the miracle of Theophilus in an anthology of the Virgin's miracles. Although the illustrations of this poem have never received the monographic study they deserve as a group, the texts have. See Arlette Ducrot-Granderye, "Etude sur les Miracles de Nostre Dame de Gautier de Coincy," Annales Academiae Scientiarum Fennicae, Series B, 25/2 (1932). In some Gautier de Coincy manuscripts the miracle of Theophilus (like the other miracles) is illustrated with a single historiated initial: e.g., Paris, BN, MSS fr. 818 (fol. 70v) and 25532 (fol. 9r). For the unusually elaborate cycle of Besançon 551 see $n .27$ above.

See chart on following page. 


\begin{tabular}{|c|c|c|c|c|c|c|c|c|c|c|c|c|}
\hline & & 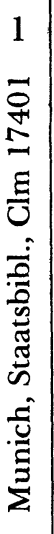 & 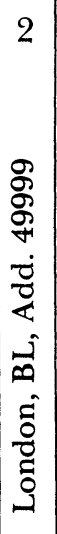 & 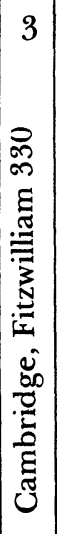 & 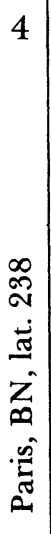 & 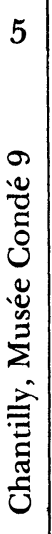 & 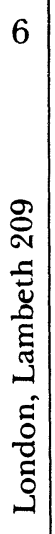 & 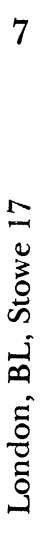 & 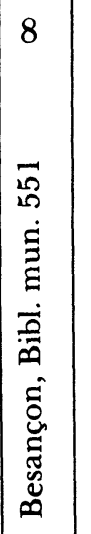 & 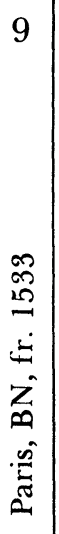 & 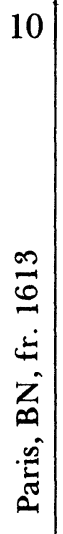 & 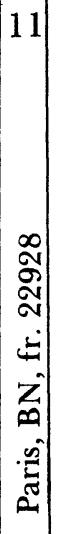 \\
\hline \multirow{9}{*}{ 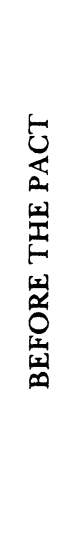 } & Theophilus as Vidame & 1 & & & & & & 1 & 1 & & & \\
\hline & Theophilus chosen to be Bishop & 2 & & & & & & & & & & \\
\hline & Theophilus refuses office & 3 & 1 & & & & & & & & & \\
\hline & Theophilus is dismissed & & & 1 & & & & & 2 & & & \\
\hline & Theophilus in disgrace & 4 ? & 2 & 2 & & & & & & & & \\
\hline & Devils attack a building & & & & & & & & & & & \\
\hline & Theophilus seeks and meets Saladin & 5 & & & & & 1 & & 3 & & 1 & \\
\hline & $\begin{array}{l}\text { Theophilus meets the devil: } \\
\text { the pact is negotiated }\end{array}$ & & & & & & 2 & 2 & 4,5 & 1 & 2 & \\
\hline & THE PACT IS SEALED & & 3 & 3 & & 1 & 2 & 3 & 6 & 2 & & \\
\hline \multirow{6}{*}{ 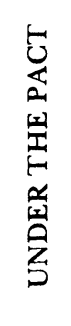 } & Theophilus is reinstated & & 4 & & & & & & & & & \\
\hline & Theophilus receives money & & & & & & & & 6 & & & \\
\hline & Theophilus distributes alms & 7,8 & & & & & & & 10 & & & \\
\hline & Theophilus receives a fish & & & & & & & & 7 & & & \\
\hline & Theophilus is worshiped by the devil & & & 4 & & & & & & & & \\
\hline & Theophilus builds a church & & & & & & & & & & & \\
\hline \multirow{5}{*}{ 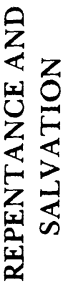 } & Theophilus enters a church & & & & & & & & 11 & & & \\
\hline & PRAYER TO THE VIRGIN & 9 & 5 & 5 & 1 & 2 & 3 & 4 & 12,13 & 3 & 3 & 2 \\
\hline & The Virgin appears to Theophilus & & 6 & & & & & & 14,15 & & & \\
\hline & THE PACT IS RETRIEVED & & 7 & 6 & & 3 & 4 & & 17 & & & \\
\hline & THE PACT IS RETURNED & 10 & 8 & 7 & & 4 & 5 & 5 & 18,20 & & & 1 \\
\hline \multirow{5}{*}{ 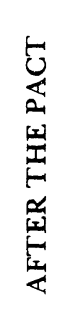 } & The pact is burned & & 9 & & 2 & & & & 21 & & & \\
\hline & The pact is offered to the Bishop & 11 & & & & & & & & & & \\
\hline & Theophilus's penance & & & & & & & & & & & \\
\hline & The Bishop's sermon about Theophilus & & & & & & & & 22 & & & \\
\hline & $\begin{array}{l}\text { Theophilus's funeral and the } \\
\text { ascent of his soul }\end{array}$ & 13 & 10 & 8 & & & & & 25 & & & \\
\hline
\end{tabular}

